\title{
NBSIR 75-973
}

\section{Guide to Improving the Performance of a Manipulator System for Nuclear Fuel Handling Through Computer Controls}

John M. Evans, Jr., Ph.D. James S. Albus, Ph.D.

Anthony J. Barbera, Ph.D.

Robert Rosenthal

William B. Truitt

Office of Developmental Automation and Control Technology Institute for Computer Sciences and Technology

National Bureau of Standards

Washington, D. C. 20234

November, 1975

Final Project Report

Prepared for

Oak Ridge National Laboratory

Oak Ridge, Tennessee $\mathbf{3 7 8 3 0}$ 



\section{GUIDE TO IMPROVING THE}

PERFORMANCE OF A MANIPULATOR

SYSTEM FOR NUCLEAR FUEL

HANDLING THROUGH COMPUTER CONTROLS

John M. Evans, Jr., Ph.D.

James S. Albus, Ph.D.

Anthony J. Barbera, Ph.D.

Robert Rosenthal

William B. Truitt

Office of Developmental Automation and Control Technology Institute for Computer Sciences and Technology

National Bureau of Standards

Washington, D. C. 20234

November, 1975

Final Project Report

\section{Prepared for}

Oak Ridge National Laboratory

Oak Ridge, Tennessee 37830

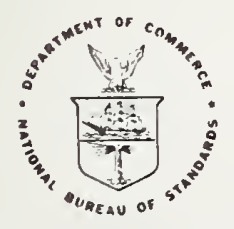

U.S. DEPARTMENT OF COMMERCE, Rogers C.B. Morton, Secretary James A. Baker, III, Under Secretary

Dr. Betsy Ancker-Johnson, Assistant Secretary for Science and Technology

NATIONAL BUREAU OF STANDARDS, Ernest Ambler, Acting Director 
I. INTRODUCTION

II. OPERATIONAL REQUIREMENTS

III. CONTROL REQUIREMENTS

IV. SUMMARY AND CONCLUSIONS

Appendix A: LETTER FROM AEC TO NBS: NOV. 13, 1974

Appendix B: DESCRIPTION OF NBS COMPUTER CONTROL SOFTWARE-

Appendix C: MANIPULATOR/COMPUTER INTERFACE DESIGN

Appendix D: INTERFACE DRIVERS AND TEST SOFTWARE

Appendix E: ROBOT CONTROL PROGRAMS 


$$
\text { • }
$$




\section{INTRODUCTION}

The Office of Developmental Automation and Control Technology of the Institute for Computer Sciences and Technology of the National Bureau of Standards works to assist other Government agencies in the efficient application of computer controlled automation systems. The products of the program are consulting and advising services, standards and guidelines on interface and computer control systems, and performance specifications for the procurement and use of computer controlled manipulators and other computer based automation systems. These outputs will help other agencies and industry apply this technology to increase productivity and improve work quality by removing men from hazardous environments.

In FY 1974 personne] from the Oak Ridge National Laboratory (ORNL) visited NBS to discuss the feasibility of using computer control techniques to improve the operation of remote control manipulators which support their HTGR fuel refabrication program. Subsequent discussions led to an agreement for NBS to develop a conceptual design for a computer control system for the remote control electromechanical manipulators in the Thorium Uranium Re-cycle Facility (TURF) at ORNL (See Appendix A). Following the above agreement, an ORNL decision was made to assign the task of developing the conceptual design to ORNL personnel.

The role of NBS, in support of the ORNL conceptual design, was shifted to responsibility for development of complete computer programs for testing the ORNL computer interfaces and for controlling the ORNL manipulator as a robot in both point-to-point and continuous path modes. In addition, NBS agreed to serve as a consultant regarding the ORNL conceptual design.

ORNL has provided the required conceptual design, and this conceptual design was reviewed and endorsed by NBS. Following agreement on the conceptual design, the required computer programs to implement it were developed at NBS. These programs are written in FORTRAN to insure transportability, and they have been tested in the NBS Automation Laboratory prior to release to ORNL. The proposed modiffcations wlll result in at least a ten-fold increase in the rate of task completion for the remote manipulators with a substantial reduction in fatigue to the manipulator operator. 
As a result of discussions with ORNL the following operational requirements for HTGR fuel refabrication were transmitted to NBS.

The manipulator systems servicing Cells C, D, and E of TURF are PaR Model 3000 electromechanical manipulators on overhead bridges. The standard controls are rate control switches for each separate joint on a control box operated from outside of the cell; if necessary, TV viewing is used to assist the operator.

The TURF facility already had the PaR manipulators installed when this project began. The concepts presented here are directly focused for that facility, as directed by the ERDA/NBS agreement. However, the computer control concepts discussed in this report are generally applicable to any remote control electromechanical manipulator and should this benefit other ERDA facilities and to other Government programs.

Significant improvements in the operation of such remote manipulators are possible through the addition of more advanced master-slave control systems. For example, Whitney and Nevins at the Charles Stark Draper Laboratory document a full order of magnitude improvement in task completion time with master-slave control systems compared with switch box control systems.

Operation of the High Temperature Gas-Colled Reactor (HTGR) Fuel Refabrication Pilot Plant (FRPP) includes such operations as refilling feeder bowls, moving assembled fuel elements to annealing furnaces, and changing furnace liners. ORNL personnel have indicated that these operations will be performed automatically by the manipulator system if automation demonstrates its superiority in rate of task completion.

In addition, the manipulator system will be required to perform remote maintenance operations for the fuel reprocessing equipment, including coupling disconnects, nonroutine high dexterity operations, and movement of major pleces of processing equipment to Cell B for repair. These complex, non-repetitive tasks will require a manual master/slave control mode.

The manipulator control concepts required to carry out those operations are considered next. There are two key elements in the proposed facility modifications: The addition of position servos to the manipulator joints to allow master/slave control and the addition of a small control computer to allow automatic control. The computer will be able to provide robot operation of the manipulator and automatic traversing and positioning of the overhead crane; it will also provide control of remote TV cameras and monitoring of total system operation for failure and for collision avoidance. 
The problem of controlling a manipulator system can be thought as a continuous spectrum from direct rate control of each joint (as in current remote control manipulator systems) up to complete autonomous adaptive operation under computer control. Greater flexibility and manipulative capability is gained by moving along this spectrum, augmenting man's ability to operate the remote manipulators through the addition of servo and computer controls.

A phased approach (recommended by ORNL and endorsed by NBS) to improve the operation of the manipulators for the HTGR FRPP is as follows:

\section{Step 1: ADD POSITION SERVOS \\ Step 2: ADD MASTER/SLAVE CONTROL. \\ Step 3: ADD COMPUTER INTERFACE \\ Step 4: ADD COMPUTER SOFTWARE FOR ROBOT CONTROL}

These steps are now considered in detail.

Step 1: ADD POSITION SERVOS

Adding position servos to each joint of the manipulator is one of the most expensive and difficult steps, but it is absolutely essential to any additional improvements.

Position Sensors

Position servos require sensors that will measure the position of each joint. Candidates sensors are potentiometers, encoders, and resolvers. The criteria for selection are reliability, wires per joint, and noise immunity.

Potentiometers are the least expensive sensor, but they provide an output that will be susceptible to noise. In addition, voltage drops over the extensive cables required to connect the potentiometers with the controls external to the cell will appear as a position dependent error. Potentiometers require one lead (plus a power supply and a common ground) per joint.

Encoders may be either incremental or absolute. Incremental encoders give pulses at equally spaced angular increments. Absolute position is formed by summing the pulses in an up-down counter. Incremental encoders require two wires per joint for the two pulse trains required to determine the direction of motion (plus a common ground and common power supply lead), but they can be susceptible to pulse noise or power failure. The number of electric motors (noise sources) present on the manipulators and in the FRPP equipment dictate against incremental encoders if automatic operation is desired. Absolute encoders have good noise immunity, but require 1 lead per bit. This means that 12 bit encoders need either 12 wires per joint or a multiplexer in the radioactive environment.

Resolvers offer the best alternative. Resolvers are extremely reliable, and give good noise immunity. They require three leads per joint (plus a common ground).

\section{Velocity Sensors}

The manipulator arm positioning tolerance defined by 0ak Ridge requires a position resolution of one part in ten-thousand. This high resolution requires such a high position feedback gain that compensating velocity feedback is required to achieve a stable position servo. Commercial dc servo motors are available which incorporate a dc motor tachometer to provide the required velocity feedback voltage.

Position Servos

Once position resolvers and dc servo motors with tachometers are mounted on the joints of the manipulator, the control loop can be established by feeding velocity and 
position voltages into a single operational amplifier. The output of the amplifier can then directly drive a power amplifier which in turn drives a dc servo motor, as shown in Figure 1.

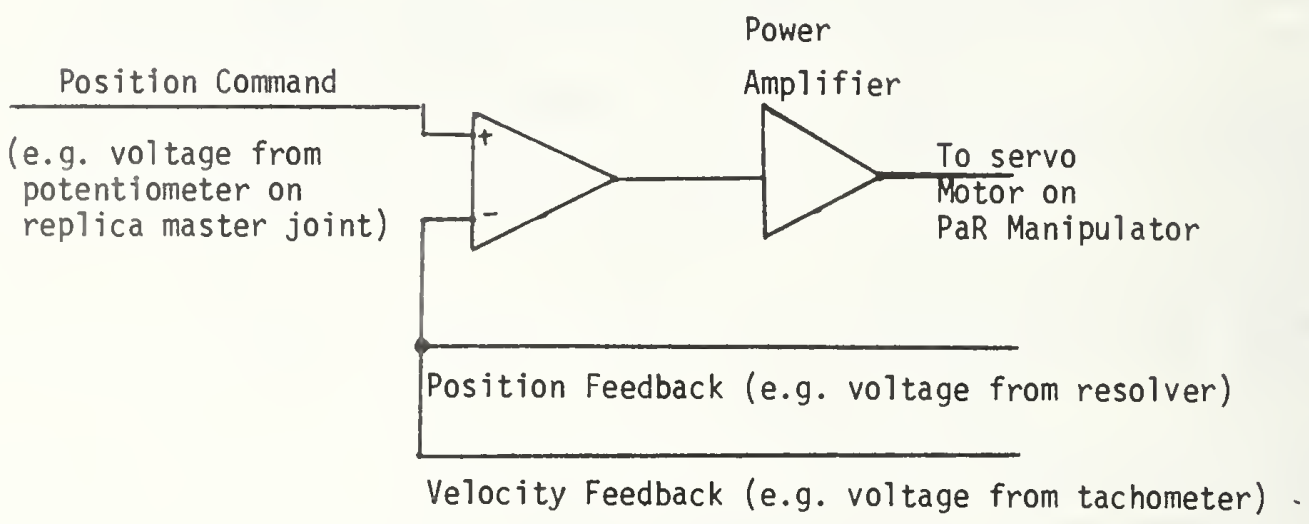

Figure 1 Servo Schematic

\section{Step 2: ADD MASTER/SLAVE CONTROL}

Once a closed loop control has been added, a replica master can be for control; ORNL already has such a master control with articulations matching the existing manipulator The outputs of potentiometers on each master joint provide the position commands for the manipulator position servos. The operator moves the hand of the master in a desired motion, and a PaR 3000 is servoed to follow that motion. This should result in increased operating speed by up to an order of magnitude by allowing the operator to simulataneously operate and coordinate the motions of all of the joints to achieve the desired hand motions. This addition is considered essential to expedite FRPP maintenance operations.

\section{Step 3: ADD COMPUTER INTERFACE}

The addition of a small computer to the control system allows a further increase in operational efficiency. The computer and interface circuitry is a major expense, but one that will result in clear cost benefits in allowing automatic operation of the manipulator. In particular, once the proper trajectories are recorded, the computer can move the manipulator around the cells within the accuracy of the servos and at maximum velocity without any danger of collision with FRPP equipment.

\section{Computer Interface}

The design of a computer interface depends on the specific computer hardware configuration and its location with respect to the manipulator.

The interface design used by NBS is described in Appendix $C$. The computer is approximately 100 feet from the manipulator. The interface consists of:

\section{Input}

1) A commercial $A / D$ converter consisting of a 64 channel multiplexer rated at $20 \mathrm{KH} 2$ word rate with single-ended inputs.

2) A 16 bit parallel connection to a OR-11C general purpose interface card on the POP-11 control computer. 
Output

3) A 16 bit paraliel connection from the DR-11C to the D/A circuitry.

4) A 16 channel D/A output 15 bit, sequential addressing only. 16th bit is for reset.

The interface system, utilizing a single 16 bit parallel $1 / 0$ interface, $0 / C$ does not use interrupts, all I/O is handled on a polled basis. Therefore, this system design works well with any Operating System capable of supporting a "stand-alone" program. All inputs are read into the input buffer; and control calculations are made using commands which are loaded into an output buffer and then transmitted to the dedicated $D / A$ converters for each joint servo. See Figure 2.

The important elements of an interface design recommended for the HTGR FRPP facility are:

1) Use of single channel input and output.

2) Use of minimum interrupt structures except for safety interlocks. The use of a a real-time operating system that is interrupt driven will require use of interrupts for input/output control.

3) Use of commercial $D / A$ and $A / D$ units that will be more reliable and less expensive than in-house designs;

4) Use of a control panel with several off/on switches and a potentiometer. (This control panel has proven to be very useful in programming and controlling computer controlled manipulators.)

Bringing up a reliable, noise-free interface is often an extensive engineering effort. Simplicity of design is very important. The test programs in Appendix $D$ have proven helpful in debugging interface and communications circuits.

Step 4: ADD COMPUTER SOFTWARE FOR ROBOT CONTROL

The software for automatic (robot) operation of the manipulator system is straightforward. NBS has followed a hierarchical structure to software development consisting of 5 levels:

Leve1 1. Interface Drivers: Interface drivers are programs written in assembly language. They isolate the computer dependent I/0 from the higher level software programs.

Level 2. Trajectory Control: Trajectory control of the robot, accomplished with a record-and-play-back technique, allows the robot to do both point-to-point and continuous path trajectories. Also, coordinate transformations of recorded trajectories are accomplished under program control.

Level 3. Elemental Moves: Elemental moves such as "docking" are accomplished using sensory feedback to allow adaptive control in a partially unstructured environment.

Level 4. Simple Tasks: Simple tasks, such as "replace furnace liners", are sequences of elemental moves.

Level 5. Complex Tasks: Complex tasks are the highest level control programs, such as "move broken index table to Cell B for repair". This program level calls up sequences of lower level programs. 


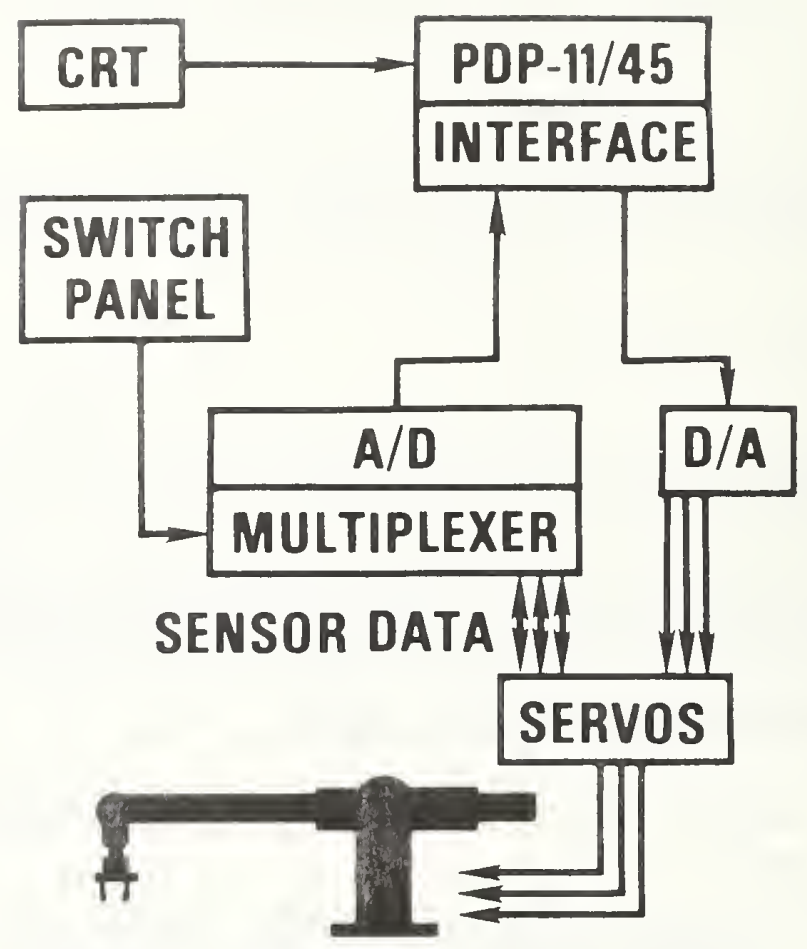

FIGURE 2. LABORATORY INTERFACE SCHEMATIC 
Most of the operations required of the manipulators for the FRPP can be carried out by implementing Leve] 1 and Leve] 2. In particular, implementing the continuous path and point-to-point trajectory record and play back at Level 2 allows execution of the automatic operations required. These programs are described and listed in Appendicies $B, D$, and $E$.

For initial experiments it is recommended that only interface drivers and trajectory control programs be implemented. Testing for accuracy, repeatability, and stability of the servos and computer controls can be carried out with this level of control.

Coordinate transformations are useful in conjunction with sensor inputs for Level 3. Coordinate transformation capability will be needed if proximity, force, or touch sensors are required for docking, moving fuel elements to the annealing furnace, inserting furnace liners, or similar operations. Sensors on the hand of the manipulator or on external objects in the environment of the manipulator generate data that is in the coordinate system of the sensors themselves. For example, force sensors in the manipulator wrist will generate $\mathrm{Fx}, \mathrm{Fy}$, and $\mathrm{Fz}$ data referred to the wrist orientation. Closed loop control using this data inplies that motions of the manipulator must be carried out in the same coordinate system as the sensor data (e.g. inserting a furnace liner requires forces orthogonal to the axis of the furnace should be zero and the manipulator must therefore move exactly along the axis of the furnace). This closed loop control in turn requires transforming $x$ y $z$ motions into coordinated motions of the manipulator joints. Coordinate transformation capability can be added later, after the need for sensory feedback has been determined.

It should be noted that jigging and compliance can replace the need for Level 3 control programs in some cases. In particular, robot manufacturers in both the U.S. and Japan have used compliance and vibration with open loop positioning for complex assembly tasks. 
IV. SUMMARY AND CONCLUSIONS

The operational requirements described in Part II may be achieved by implementing the following steps:

Step 1: Add resolvers and tachometers to each joint of the manipulator. Then close servo loops with position and velocity feedback.

Step 2: Add master/slave control with a replica master using position transducers to drive the manipulator position servo loops.

Step 3: Add mini-computer with appropriate interfaces.

Step 4: Implement robot control programs for point-to-point and continuous trajectory control.

Steps 1 and 2 together give the capability of master/slave control for maintenance and repair and other non-repetitive operations. Steps 3 and 4 allows automatic (robot) operations for routine repetitive tasks.

Testing of these modifications should be carried out before additional change are made. The results of testing Steps 1 through 4 will determine the need for force, touch or proximity sensors and Leve] 3 control programs to carry out routine operations such as docking, filling feeder bowls, and replacing furnace liners.

Implementation of these proposed modifications will result in increased speed of operation of the manipulator and overhead bridge by at least a factor of 10 and will allow routine transfer and service operations to be accomplished automatically. 
Appendix A:

Letter from ERDA (then AEC) Oak Ridge Operations Office to NBS, November 13, 1974, requesting a conceptual design study of a programmable control system for an electromechanical manipulator system. 
Appendix B: DESCRIPTION OF NBS COMPUTER CONTROL SOFTHARE

\section{Introduction}

Recently a series of experiments was conducted in the ICST Automation Technology Laboratory in which the computer control of a mechanical manipulator was studied. In this experiment, a manipulator was interfaced to a mini-computer.

The lowest levels of computer software for controlling this manipulator as a robot are described in this report. The discussion will describe software strategy and will examine the general problem of specifying a mini-computer for program development and real time control.

The system described is a PDP-11 computer with D/A and A/D interfaces, a hydraulic power anthropomorphic manipulator system with full hardware servos, and an exoskeleton harness control for master/slave operation. The techniques discussed are generally applicable to the computer control of manipulators.

\section{a. Problem Statement}

While the main function of the laboratory mini-computer is to execute the manipulator control programs, program preparation, compilation, linking and loading must also be performed. In general, a dedicated laboratory mini-computer must have more than just a central processing unit (CPU) and a program store (core) to carry out these program development steps. The issues of what is required in the mini-computer and its associated hardware are discussed as they relate to the problem of sizing a machine (the mini-computer) to do the necessary control functions. First, a description of the software system developed in the ICST laboratory is discussed. Then, a description of the necessary elements in the mini-computer architecture as well as a general description of a possible mini-computer configuration is presented.

\section{b. System Overview}

The laboratory mini-computer is the central coordinating point for all of the manipulator hardware. A 16 bit general purpose parallel interface connects the computer to the manipulator. The interface output buffer is connected to a D/A converter designed by NBS. The 16 bit parallel output is switched sequentially to buffer registers. These buffer registers drive digital to analog (D/A) converters which drive the servo valves on the joints of the manipulator. There is one D/A converter for each joint of the manipulator.

Input to the computer from the manipulator hardware is from a 64 channel analog to digital (A/D) multiplexer and converter. The signals to the multiplexer are derived from potentiometers and other sensors connected to the manipulator, the exoskeleton, and a special panel containing function switches and potentiometers. The A/D converter is connected to the input buffer of the general purpose interface board.

In the system described here, several software programs were prepared and executed on the mini-computer. The programs interact with the operator through the operators's console which also provides system status information. The system software was developed in a modular fashion so that new applications could easily be built by incorporating existing software.

\section{Software System}

The ICST software system for mini-computer control appears as a hierarchy of modular control functions easily organized into a comprehensive applications package for controlling a manipulator. Three hierarchical levels of software are defined. At the lowest level are assembly language input and output drivers for the interface to the manipulator. At the next level are programs for teaching the manipulator to carry out various trajectories. At the highest level are programs for coordinate 
transformations which allow trajectories to be defined in an experimental (laboratory) coordinate system. The first two levels are discussed here.

Appropriate sensor input to predefined A/D converter channels enable the minicomputer to control the manipulator in response to the sensory stimuli. Acoustic positioning feedback sensors, force sensors and pressure sensors have already been used in the laboratory experiments. The hierarchy of software programs used to provide the control functions is described.

\section{a. Hierarchy}

\section{Lowest Leve1}

At this level, two driver modules are specified. ARMIN is the driver which transfers data from the A/D multiplexer into a core buffer and ARMOUT transfers data from a core buffer to $D / A$ converters which are connected to the servo valves which control the manipulator joint positions.

\section{Second Leve1}

The first application program in the system is called SANDF. SANDF is a mnemonic for "store and forward". The program uses the driver program ARMIN to read the input channels. Included in the input channel data are the positions of the exoskeleton joint angles. These exoskeleton channel datum are scaled by SANDF after which SANDF calls the driver ARMOUT. ARMOUT writes the scaled exoskeleton positions to the servo valves of the manipulator. In this way, SANDF is able to control the manipulator by causing it to track the exoskeleton. Successive calls to SANDF will cause the manipulator to follow the trajectory of the exoskeleton.

Building upon this existing software, an application program called ARM was designed to behave much like a tape recorder. In the ARM program, the exoskeleton positions are stored; then forwarded to the manipulator with the SANDF program. At the operator's request, the manipulator coordinates are recorded by the program and stored in the mini-computer. Much like a tape recorder, the operator can play back these coordinates and cause the manipulator to traverse the pre-recorded trajectory. ARM allows us to operate at the sophistication level of commercially available industrial robots.

Embellishments to this program are worth noting. By utilizing the file system of the mini-computer, sets of coordinates can be saved, and later retrieved by name for play back. Also, during play back, a special function button panel can be accessed. This panel has a potentiometer that can be manually set by the operator. The program ARM uses the potentiometer setting to indicate the speed at which the play back is to occur. While the maximum play back is limited by the execution time for the program, delays in play back are introduced by reference to a routine called TIMOUT which accepts, as an argument, a delay specified in 60ths of a second. The potentiometer value is approprimately scaled to indicate a suitable delay. Full speed play back is significantly faster than the recording speed so that the play back speed ranges from almost twice as fast as normal, to very very slow -- where each recorded point in the trajectory is easily noticeable.

A second program, PNTPNT, allows point-to-point trajectories to be recorded and executed. Points are recorded when the carriage return is typed on the control terminal rather than at equally spaced time intervals.

A third program, NEWARM, combines these two programs and adds interpolation between stored points along the trajectory during play back. 


\section{Software Requirements}

While the main function of the mini-computer is to execute the control programs for the manipulator, program preparation, compilation, linking and loading must also be performed. The basic operating system usually supplied with the mini-computer should provide these functions.

\section{a. Program Preparation}

Once conceived by the programmer, the program must be entered into the computer system. Typically, the mini-computer is supplied with a keyboard control terminal and an operating system containing an editing system for entering new programs or modifying existing ones. If the mini-computer has a disc based operating system (DOS), the program source files are easily maintained as text files on the system disc. DOS can also be used to support the compilers and/or assemblers used to transform the source language statements into machine instructions. If no disc is available, some other means of storing the source program and compilers is required. Usually this is done with paper tape. Such systems, while less expensive to procure, generally require significant amounts of time just to do simple operations like compiling programs. Thus, the initial cost savings of a paper tape system are quickly absorbed in non-productive labor costs.

\section{b. Program Compilation (Assembly)}

Once the programmer is satisfied that the text of his source file is correct, he can compile the program; if the text of his source file is an assembly language program, he can assemble his program. Higher level language programs, which require compilation, are usuallv easier to read, easier to write, and easier to debug; but, inefficiencies in machine code are generally introduced. Many systems will therefore, allow the main programs and many subroutines to be written in a higher level language which is compiled, and allow the routines which require extreme efficiency to be coded in assembly language. In order to put together the compiled programs and the assembly language programs in preparation for executing the system, a processes called linking is performed.

\section{c. Program Linking and Loading}

To link programs together into a complete system requires a special operating system routine called a "Linker". This program assigns core locations to the variables defined in the user programs and assigns space in main memory for the actual programs to be executed. The output of the linker program is typically a file containing a core image of the linked program, or a file containing an image of the linked program along with special loader instructions specifying how the linked program is to be loaded. In any case, once the program is linked, a loader is capable of preparing a core image which can be executed by the CPU.

\section{d. Program Execution}

Once the loader is finished preparing a core image of the linked program, the loader transfers control of the CPU to the start address of the loaded program.

\section{Hardware Configuration}

The hardware configuration for a mini-computer used to support program preparation is often significantly different from that of a mini-computer used to execute a dedicated user program. In one case a disc based operating system used to edit, compile, assemble, link and load, might require a high speed line printer for listings of source programs, a disc pack peripheral for mounting user program libraries of commonly used debugging aids and much more. The dedicated user program on the other hand will only require a few peripherals specific to the needs of the intended application, for example, an interface to a manipulator. 


\section{a. Program Preparation}

Experience indicates that in order to do program preparation on a minicomputer a disc based operating system is prefered to a paper tape system.

Also at least some hard copy printing device is necessary to get listings of the programs written as well as any data the program may generate. While a high speed 1 ine printer is necessary on a machine dedicated to program development, the high cost is not justified for intermittent program development sessions. Finally, a mountable secondary storage medium such as magnetic tapes or disc packs is necessary when installing the manufacture's operating system. Mountable storage is also very useful whenever large volumes of data are collected by the application or user program.

\section{b. Program Execution}

The mini-computer configuration requirements for program execution are much different than for program perparation. The only peripheral devices required are those which are accessed by the program. The normal peripherals used in program preparation however, can often serve dual purposes. The operator's console can be used to list information regarding the status of the user program. Secondary storage is also used if the user program generates large volumes of data. Also, in systems where core size is limited, provisions are often made to overlay portions of the user program. This technique allows programs to be written which use more core than is available at any one time. The user program is organized in blocks or segments which can easily be swapped between core storage and disc storage. While this technique usually slows down the execution of the user program, the benefits gained in available program size are usually justified.

The special peripheral requirements used in the manipulator control programs include the parallel interface to the $A / D$ and $D / A$ converter systems. The special function button panel connected to the input A/D multiplexer provides an excellent means to control the manipulator software. Also, the visual operator feedback from the blinking lights on the multiplexer provides assurances to the operator that the mini-computer is functioning properly. This has proved to be a valuable aid during the debugging phase of the software system.

\section{Conclusions}

The intent of this report is to focus on the computer power and software techniques required to control a complex mechanical manipulator. Experiments in the ICST Automation Technology Laboratory indicate that sophisticated control functions can be performed using a mini-computer equipped with the proper peripherals and equipped with the proper software tools to develop the application programs.

In the ICST Laboratory, a DEC PDP-11/20 was originally used to control the manipulator. In preparing programs, a disc operating system equipped with a program editor, a FORTRAN compller, a macro assembler and a linking loader were used. Control programs were later transferred to a PDP 11/45 again using DOS. A11 software described here could be prepared and run on a PDP $11 / 20$ size mini-computer.

Hardware peripherals unique to the requirements of the laboratory were utilized by the applications programs. A special function button panel connected to several input channels of the $A / D$ converter proved to be a very useful and desirable operator convenience in controlling which software module was to be executed. Also, the visual feedback from the blinking lights on the $A / D$ converter reassured the operator that the programming system was operational. 
Data transfer between the laboratory hardware and the PDP-11/45 computer is handled via a DR11-C interface card in the computer. This card has 16 data input 1 ines, 16 data output lines, two interrupt lines and two sync lines, one (data transmitted) for input synchronization, and one (data present) for output synchronization.

The DR11-C is connected to the laboratory interface by forty parallel wires powered by 7406 line drivers. These are open collector circuits with resistors connected to the power supply voltage at the receiving end.

The laboratory interface hardware consists of two parts: an input section and an output section.

Input:

A sixty four channel analog multiplexer followed by a 14 bit analog to digital converter forms the heart of the input section. This is range -10 volts to +10 volts. Negative voltages are converted to 2 's complement form.

Output from the A/D converter is carried to the computer on the 16 data input lines. Since the $A / D$ converter has only a 14 bit output, the most significant (sign) bit is connected to the three most significant computer input lines. This causes the computer to read the correct values for both positive and negative (2's complement) numbers.

Data transfer between the A/D converter and the computer is signaled by a pulse on the data transmitted line. This pulse, initiated by the computer, indicates that the data lines have been sampled. This data transmitted pulse is used to step the analog multiplexer to the next input and to initiate the analog to digital conversion cycle on the new input voltage. The input software is timed to sample the input data at a rate slower than the conversion rate of the A/D system. Thus, a "conversion completed" signed is not required by the computer, and only one control line is needed to advance the converter to the next channel.

The multiplexer is operated in a sequential mode. It is reset to the zeroth channel by a reset pulse derived from the output section. Each data transmitted pulse steps the multiplexer to the next sequential channel. The input section is this completely under computer control.

\section{Output:}

A sixteen channel digital demultiplexer routes output signals from the DRII-C to sixteen holdings registers. These provide either digital output directly, or are connected to digital to analog convert so as to provide analog voltabes. Datatransfer between the DR11-C and the output section is initiated by a pulse on the data present line. The data present pulse occurs simultaneously with the appearance of data on the DRII-C output lines This pulse is delayed in the laboratory interface hardware for two microseconds before actuating the digital demultiplexer so as to allow the data lines time to settle. The delayed data present pulse gates the output data into the selected holding register and then steps the address counter to the next address.

The most significant (sign) bit of the output is decoded as a reset signal and is used to set the demultiplexer address counter to Channel 1 as well as to reset the analog multiplexer address in the input section.

Using the sign bit for control means that only 15 bits of output are available for data. Numerical is restricted to the range 0 to 32,767 . The digital to analog converts are adjusted such that numerical 0 corresponds to +10 volts; 16,384 corresponds to zero volts, and 32,767 corresponds to -10 volts. 
Appendix 0: INTERFACE DRIVERS AND TEST SOFTWARE

The following programs are included in this Appendix:

1. ARMIN: An Assembly Language input driver for the DR-1IC interface

2. ARMOUT: An Assembly Language output driver for the DR-11C interface

3. TEST: A FORTRAN program for displaying and testing the values of the $A / D$ input circuits.

4. SWTH: A staircase function generator for testing the D/A output circuits by generating a sawtooth wave form.

5. INTFC: Interface tester for testing loop from $D / A$ through $A / D$ functions which is looped back to input and displayed. Also displays nefghboring channels to test crosstalk.

6. SAAR: Sine wave generator with step size limiting for safety. Exercises all joints at once for servo and total system testing.

Notes:

These programs are written in FORTRAN and operate on PDP-11/45 under DOS. They should also operate successfully on smaller members of the PDP-11 family. Operation of these programs under RSX, UNIX, ELF or other operating systems, or operation of other mini-computers will require rewriting ARMIN and ARMOUT and review of the $1 / 0$ calls in the' programs. 
- IITLE AKMIN FOK LOW LEVEL AKM INPU'I'

- IUENT / KMRULI/

;

AKMIIV AND AKMOUT haVE simILAR DUCUMENTATION. THE I'WO PROGRAMS

SHOULD BE READ TOGETHER AS SUME DOCUHENTATION EXISTS IN

UNE AND NO'I' 'I'HE OTHER.

. CSEC'I'

THE' AKP IS CON'TRULLED BY A DRII-C INTERFACE TO THÉ PDP-11/45

UNIOUS. ALTHOUGH ALL THE INTEKRUPT FACILITY AVAILABLE WI'T

IHE URII-C IS INIACI', NU INTERKUPT'S ARE USED WITH THIS VERSIOIN

JF 'THE ARM SOF'TIARE. THE GENERAL PHILOSOYHY OF' THE SOF'WARE

IS SUCH THAT DATA TKANSEER TU AND FKOIM THE AKIA WILL OCCURE

WHENEVEK A PROGRAM WANTS AND/OR HAS THE TIME.

IHE URI1-C HAS A UINIBUS ADDRESS OF 167770

FAIS IS THE CONTKUL KEGISTER. 167772 IS THE TKANSMIT REGISTEK

AND 167774 IS THE RECEIVE REGISTER. THE A/D CONVERTER

IS RESET WHENEVER IT SEES BI'I 15 SET. AT LOCATION 24, THE A/D CONVERTER

IS RESE'I'

ALL 64 CHANNELS ARE KEAD INTO THE COMMON BLOCK NAMED ARMBUF

I'HIS IS FurikalN COMPATABLE CUMMON. ALSO THE SUzROUTINE linkAGE

IS CUMIA'I'ABLE.

VAL: : $\quad$ WUKD 25

; TIME OU'I VALUE

; IS SET AT I W WHICH CAUSES 'THIS

; RUU'IINE 'TO WAIT (SEE LOUP IS)

; LONG ENOUGH FOR IIHE A/D CONVERTER

AKIIN : : ; 'TO SETTLE DOWN BETWEEN READS.

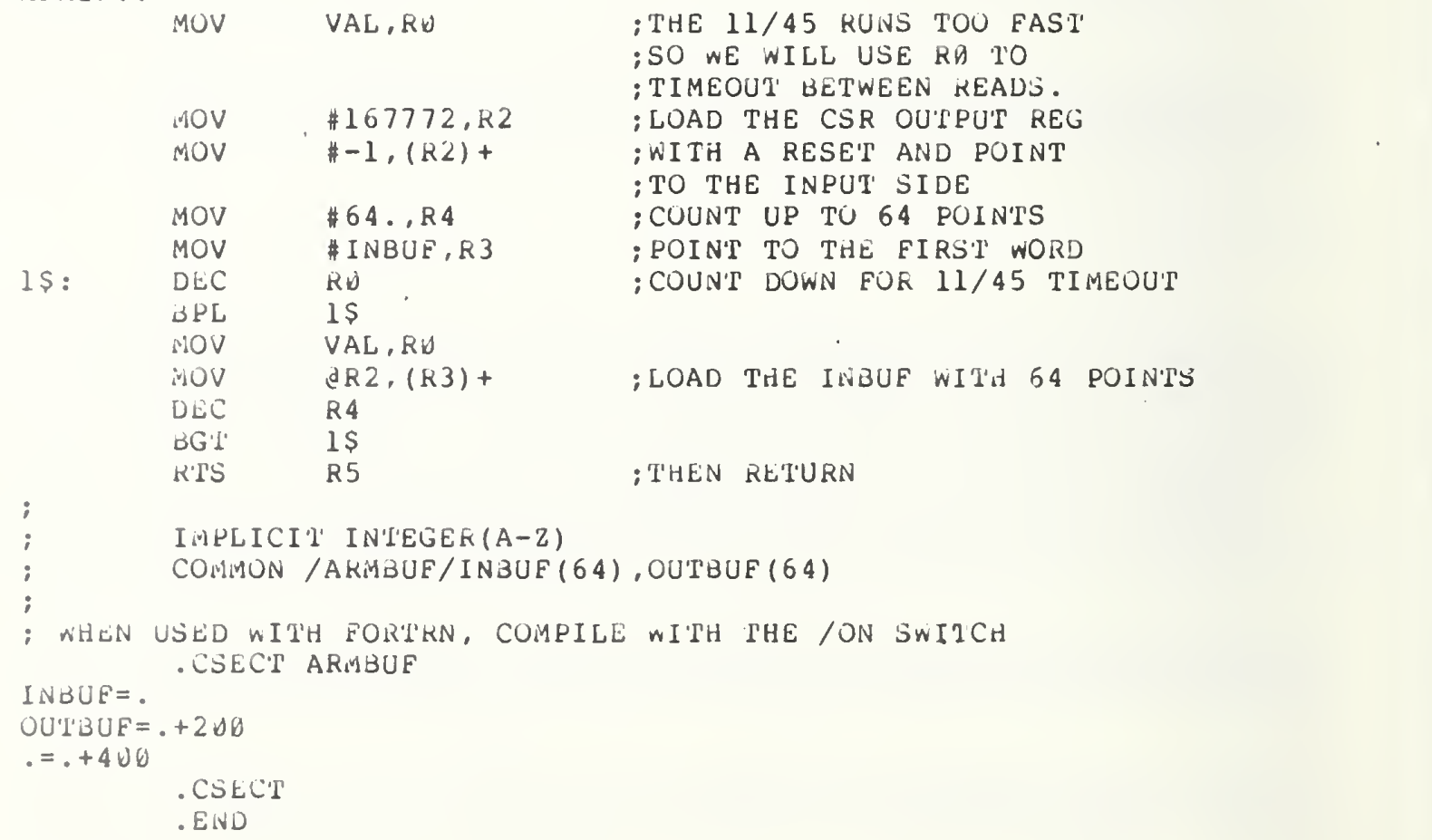




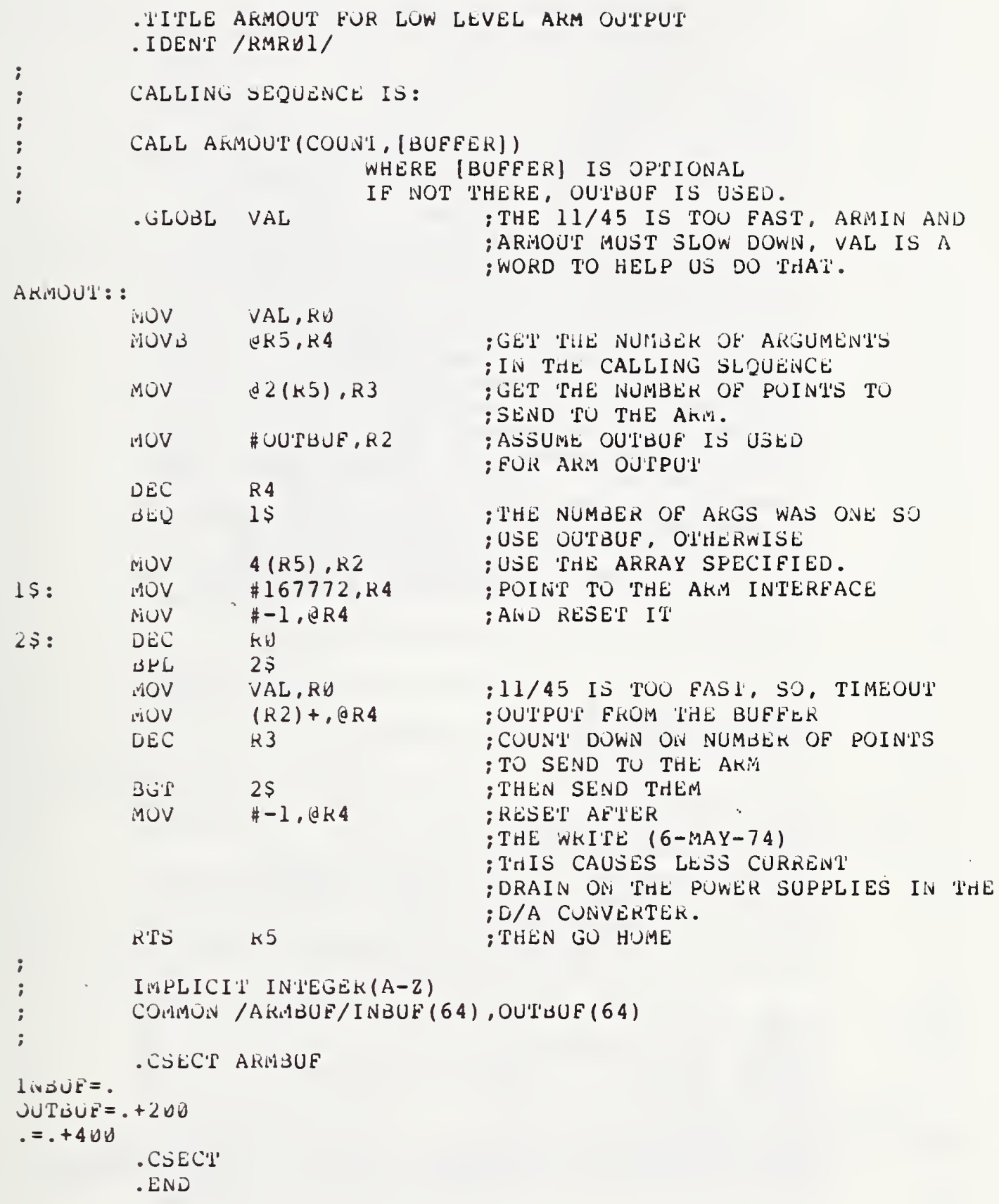


ILS'l'

THIS PKOGRAM IS USED TO 'IEST THE A/D POKTION UF 'I'HE IN'TERE'ACE'. I'I' REQUESTS AN INPU'I' CHANNEL NUMBER(Mi). I'HE VALUE ON THIS CHANNEL IS PKINTED OUI AS A BINARY NUMBER(BIN(15)). 'PHIS NUMBEK CAN OE CUMPARED 'TO 'I'HE BINAKY NUMBER FKOM 'LHE' A/D CONVERTER DISPLAY PANEL 'TU ASCERTAIN IF IHE COMPUIER IS KECEIVING 'I'HE' CORREL'T VALUE AND IF I'T IS ACCESSING 'THE' PROFER INPU'I' CHANNEL. IF A BINARY OUTPUT ON CHANNEL M IS NOT DESIKED, 'IHEN THE VALUE OF $M(M=\emptyset, M<\theta)$ IS USED AS A PLAG 'I'U (1) UIAI' 'THE CALCULATIONS 'TO COINVEKL I'O A BINAKY NUMBER AND (2) CAUSE THE PKUGRAV TO LOOF CONTINUUUSLY (AS UPPUSED 'I'O STOPPING AF'IER 100 OU'IPU'L'S). THE PRUGRAM ALSO DISPLAYS THE DECIMAL EQUIVALEN'TS OF 'LHE VALUES ON A SEQUENCE OF INPU'l' CHANNELS. THE PRUGRAM, 'I'HERERORE, REQUES'IS IHE SI'AKIING CHANNEL NUMBER(LL), AND THE EINUING CHANNEL NUMBEK(KK), 'I'HEN DISPLAYS IHE VALUES ON ALL THE CHANNELS BETWEEN THEM.

IMPLICI'I' IN'TEGER (A-Z)

COMMON / ARMBUE/INBUE (64), OUTBUE (64) DIMEINSION BIN (15)

'IHIS SECIIUIN OF CODE REQUESTS THE INPUT CHANNEL NUHBER(M) FOR THE BINARY DISPLAY, AND 'THE S'I'ART(LL) AND STOY(KK) FOR THE SERIES DISPLAY. IE UIVLY INPUT CHANNEL M IS TO HAVE' I'I'S UECIMAL EUIVALEN'I' DISPLAYED, THEN BO'H LL AND KK ARE SE' EQUAL TO $M$.

WRITE $(6,193)$

198 FORMAT ( CHANNEL NUMBER = ') $\operatorname{KCAD}(6,197) \quad M$

197 FOKMAT (I 2) WRITE $(6,200)$

ZUD FOKMAT $\left(2 X^{\circ}\right.$ SI'ARTING CHANNEL KEAAD $(6,2 \cup 1) \mathrm{LL}, \mathrm{KK}$

201 FOKMAI (I 3,I3)

c

C

C I'HIS 'DO LUOP' (FKOM STATEMEN'P 81 TO 50)

C CAUSES THE PKOGRAY TO CYCLE THROUGH 100 UU'lPUTS BEFORE REQUESTING ANOTHER CHANNEL NU.M $B E R$.

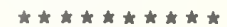

31 DU 5 \& $J=1,100$

1d CALL AKMIN

i 


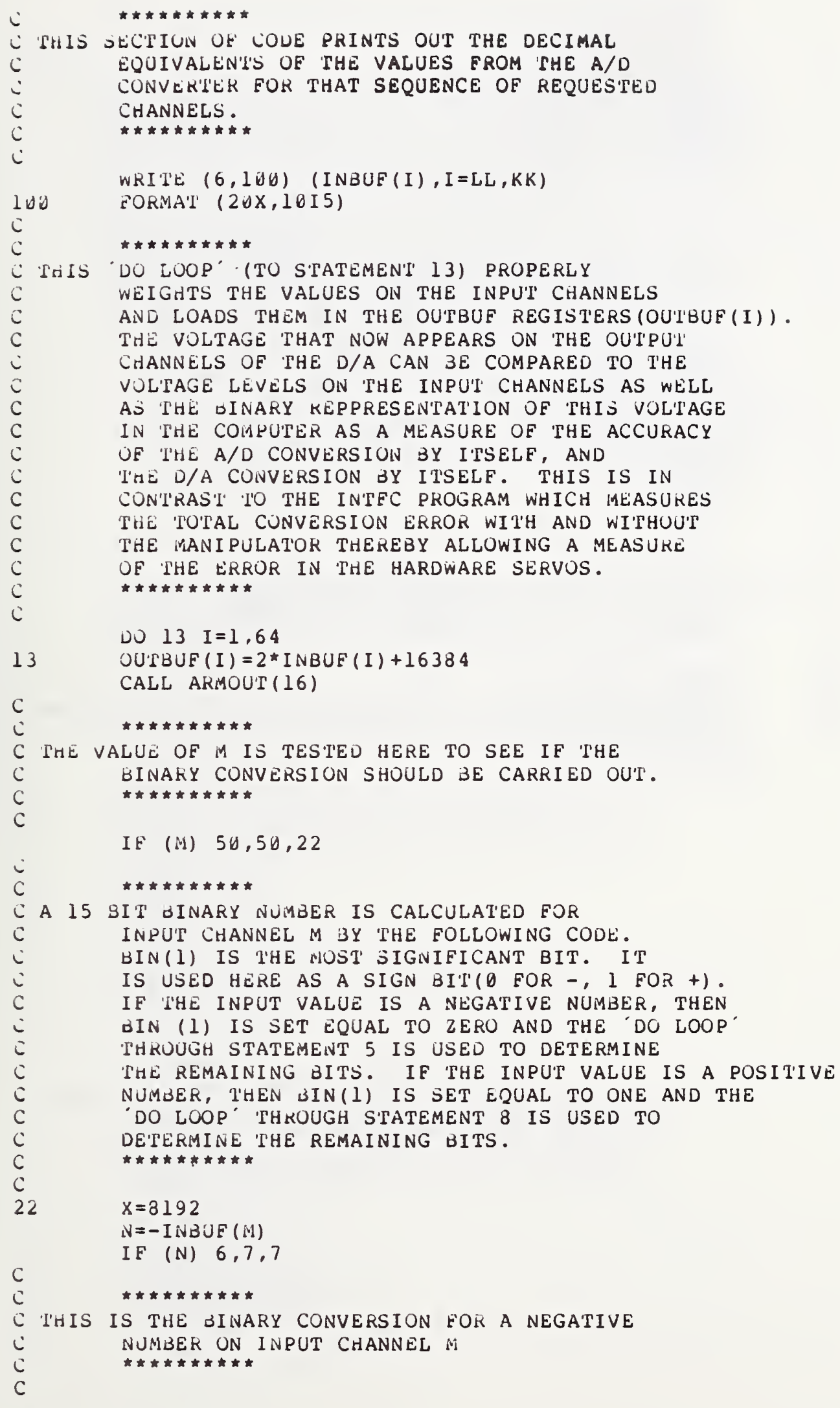




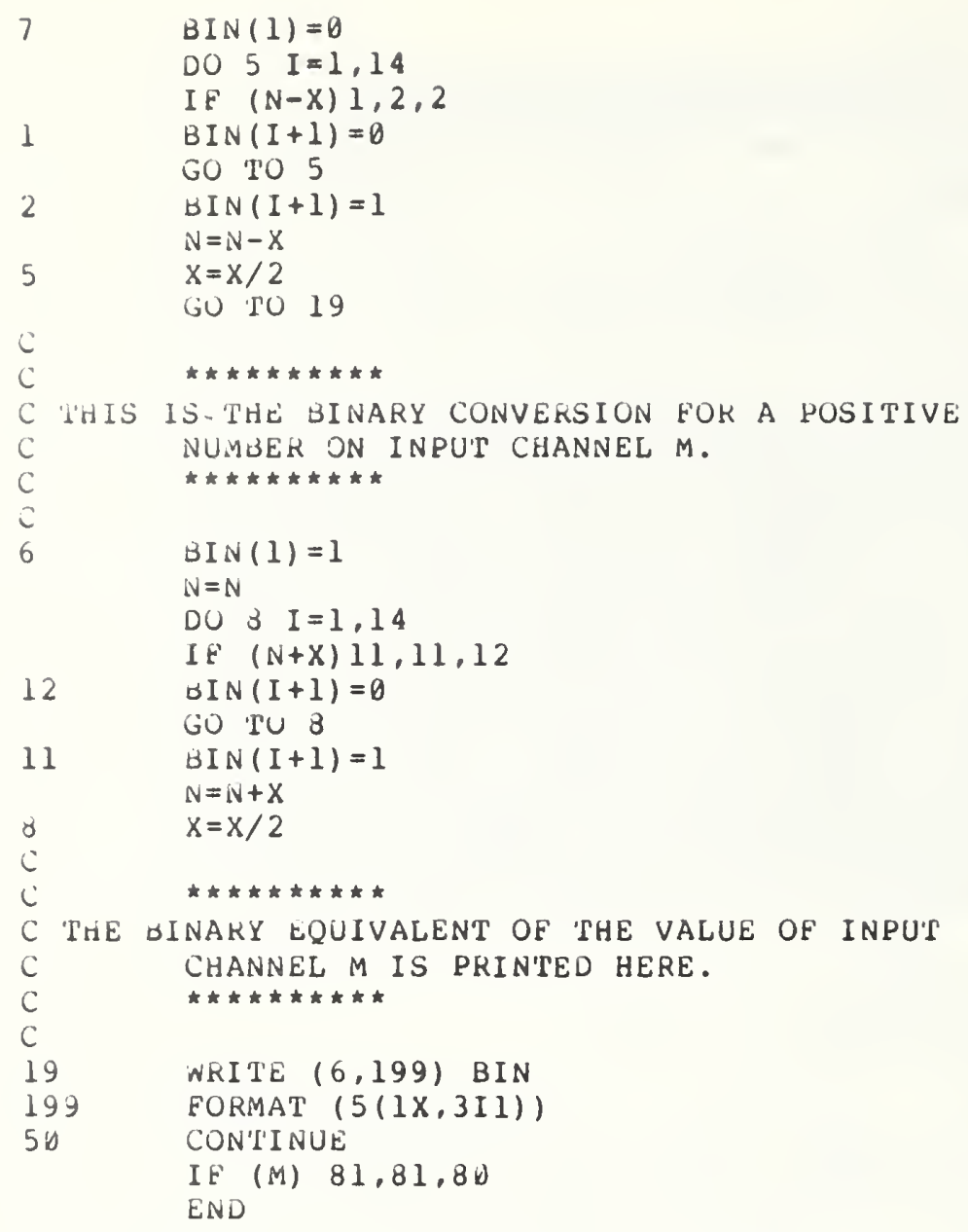


IIHIS PROGRAM GENERAI'ES A STAIRCASE I'EST FUNCIION. BUTH THE LOWER AND UPPER BOUNDARIES ARE ENTERED IN RESPONSE TU QUERIES BY THE PROGRAM. THESE SEI 'THE' BEGINNING AND ENDING VALUES OF A SIMPLE DO LUOP'. THE SIEP SIZE IS ALSO ENTERED AND BECOMES 'I'HE INCREMENTAL STEP OF 'THE 'DO LOOP'. THIS PRUGRAM CALLS THE SUBROUTINES : ARMOUT : SETERR : SETERR IS A FORTRAN LIBRARY SUBROUIINE WITH TWO ARGUMEN'IS (SETERR (C,M)) .

$C=A N$ INTEGER INDICAIING THE ERROR CLASS AFEECTED. $C=3$ IS THE VALUE FOR ARITHMETIC UVERELOW. THIS IS USED IN CASE THE INTEGER IN THE 'DO LOOP' EXCEEDS 32,767 BEFORE THE LOOP IS TERMINATED.

$M=$ AN INTEGER THAT INDICATES DIFFERENT INSTRUCTIONS. $M=-1$ TELLS THE SYSTEM NOT TO LOG MESSAGES, AND TU IGNOKE THE ERROR COUNT FOR I'HE SPECIFIED EKROR CLASS.

IN'IEGER ARMBUF, INBUF, OUTBUF COMMON/AKMBUF/INBUF (64), OUTBUF (64) CALL SETERR $(3,-1)$

$c$
$C$
$C$

PKOGRAM ASKS FOK UPPER BOUNDARY(L), THE STEP SIZE(M), AND THE LOWER BOUNDARY(K) OF THE FUNCIION.

WRITE $(6,1 \cup 1)$

IUl FORMAT (' UPPEK LIMIT OF SAWTOOTH = ' $12 \times(b$ TO 32767 OUTPUTS + 10 TO - 10 VOLTS ) $\operatorname{READ}(6,100) \mathrm{L}$

IUO FURMAT (I 5 ) WRITE $(6,102)$

102 FORMAT (" SIZE OE STEPS = ') $\operatorname{READ}(6,1 \cup U) M$ WRITE $(6,103)$

103 FORMAT (' LOWER LIMIT' OF SAWTOOTH = ') KEAD $(6,1 \cup 0) K$

aEKE, 'THE NESTED LOOP LOADS 16 OUTBUF KEGISTEKS WIIH IHE APPROPRIATE VALUES. 'IHE OUTEK LUOP CALLS AKMOU'I'(16) TO OU'PU'I' 'IHESE VALUES AFTER EACH STEP INCREMENT.

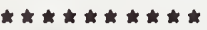

1 DO $20 \quad I=K, L, M$

DO $10 \mathrm{~J}=1,16$

$10 \quad \operatorname{OUTBUF}(\mathrm{J})=\mathrm{I}$

CALL ARMOUT (16)

20 CONIINUE

C 
C

IAIS GOTO STATEMENT CAUSES THE STAIRCASE

C FUNCTION TO REPEAT UNTIL THE PROGRAM IS C STOPPED $3 Y$ THE USER

C

GO TO 11

END 
THIS PROGRAM, WIIH ITS SUBROUTINE SAAR, IS PAKI OE AN ACCEPTANCE PROCEDURE FOR THE MANIPULATOR. I $T$ CAUSES ALL OF THE JOINTS TO BE EXERCISED SIMULTANEOUSLY IN A RYTHMIC FASHION.

ALL OF 'IHE OUTPUTS ARE SINE' WAVES. THE FREQUENCY OF EVERY JOINT CAN $3 E$ THE SAME OR DIFEERENT FROM EVERY OTHER JOINT. IF THE FREQUENCIES ARE KEPT CONSTANT, THE PHASE SHIFT OF EACH JOINT CAN BE DIFFERENT. THE AMPLITUDE UF 'IHE' NOTION UF EACH JOINT IS CONTROLLED BY ASSIGNING LIMIIING VALUES THROUGH THE SUBROUTINE SAAR. THE OVERALL FREQUENCY AT WHICH THE SYSTEM RUNS IS DETERMINED BY IHE VOLTAGE LEVEL (A PUTENTIOMETER) ON A DESIGNATED INPUT CHANNEL.

IMPLICIT INTEGER (B-R)

IMPLICIT INTEGER $(T-Z)$

COMMON $/ 2 / Z 2$

COMMON/ARMBUF/INBUF (64), OUTBUF (64)

DIMENSION ASIN $(400), K(10), A B(10), B(10), A B B(10), L(10)$

$c$

22 IS A INIEGER THAT, WHEN ITS VALUE IS ZERO, CAUSES THE PROGRAM TO WAIT AETER THE INITIAL VALUES HAVE BEEN SENT IU ALL THE JOINTS. THE PROGRAM PRINTS OUT A SIATEMENT TO THIS EFFECT AND WAITS FOR THE USER IU ENTER A +1 IN ORDER TO CONTINUE.

$22=0$

C

REQUESTS THE INPUT CHANNEL NUMBER(Q) WHICH NILL CONTROL THE OVERALL FREQUENCY OF THE SYSTEM.

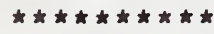

WRI'I'E $(6,90)$

FORMAT( $3 X^{\prime}$ THE FREQ OF THE OUTPUT CHANNELS WILL BE CONTROLLED'/ $13 X^{\circ} B Y$ 'IHE VOLTAGE ON A REF INPUT CHANNEL'/3X'REF INPU'T

1 CHANNEL NUMBER $=$ ')

$\operatorname{READ}(6,93) \mathrm{Q}$ 







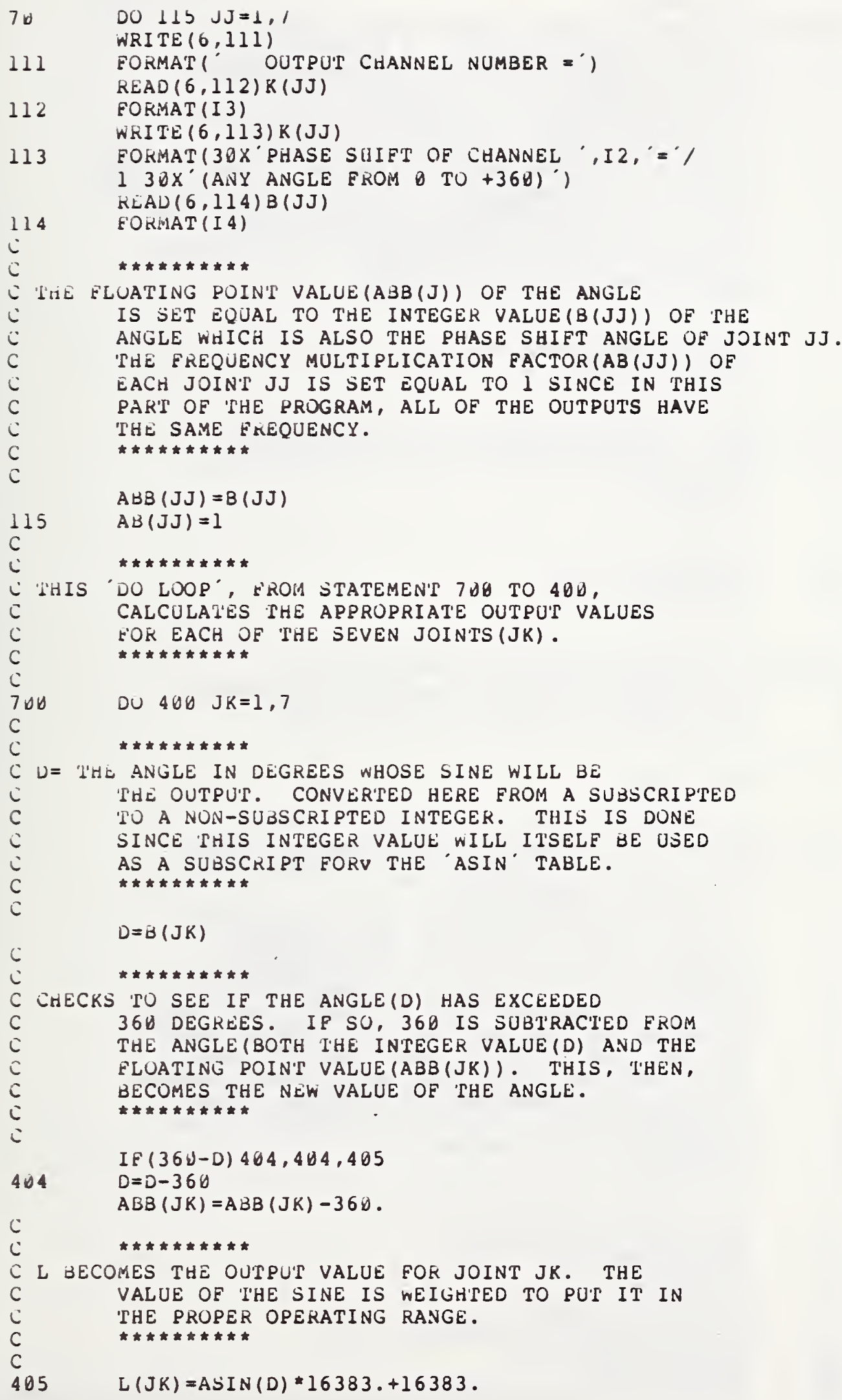

C

L BECOMES THE OUTPUT VALUE FOR JOINT JK. THE VALUE OF 'I'HE SINE IS WEIGHTED TO PUT IT IN THE PROPER OPERATING RANGE.

c 
ABB (JK) IS THE CURRENT FLOATING PUINT VALUE

OF 'IHE JOIN'T'(JK) ANGLE. A FLOATING POINT

VALUE IS USED SINCE THE ANGLE MAY SOMETIMES

BE INCREMENTED BY A VALUE LESS THAN ONE.

'IHIS OCCURS WHEN THE PRODUC'T OF AB(JK) *AX

IS LESS THAN ONE. AB(JK) MAY HAVE BEEN

ASSIGNED A VALUE LLSS THAN ONE BY THE USER(SINCE

$A B(J K)$ IS THE FREQUENCY MUL'IIPLIER FAC'TOR). THE

VALUE OF AX IS DETERIINED BY THE VOLTAGE LEVEL

ON THE DESIGNATED INPU' CHANNEL(Q) WHICH

COIVIKOLS THE OVERALL EREQUENCY OF THE SYSTEM.

ITHS AX MAY BE $<=$, OR $>$ ONE.

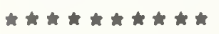

$A B B(J K)=A B B(J K)+A B(J K) \star A X$

$B(J K)=A B B(J K)$

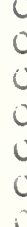

IHE OUTPUI CHANNEL NUMBER(K(JK)) IS CHANGED

ERUM A SUBSCRIPTED TO A NON-SUBSCRIPTED(N)

C INTEGER.

$\therefore \quad N=K(J K)$

$406 \quad$ OUTBUE $(N)=L(J K)$

CALL SAAR

s.

ARMIN IS CALLED TO BRING IN THE VALUE OF

'IHE REFERENCE' INPUT CHANNEL(Q) T'O CONTROL

THE OVERALL EREQUENCY OF THE SYSTEM.

CALL ARMIN

C

C' 'IHE' VALUE OF lHE REFEREINCE INPUI' CHANNEL(Q) GOES

$C$ FROM $\triangle$ IO +10 VOLTS PROVIDING INPU'I VALUES OF

U TO -81.92 RESPECTIVELY.

THE FOLLOWING CODE IS USED TO GENERATE A

ELOATING POINT NUMBER(AX) THAT TAKES ON

VALUES OF $\forall .012$ TO 11.24 . THIS NUMBER IS

MULTI PLIED BY THE DELTA INCREASE (AB(JK)) OF

'THE ANGLE EOR EACH JOINT TO PROVIDE AN OVERALL

VARIATION IN THE SPEED THAT THE SYSTEM RUNS.

'IHAT IS, THE SPEED OF THE SYSTEM IS VARIED

BY HAVING INHE POINTS COME OUT OF THE COMPUTER

AT' A CONSTAN'T RATE, WHILE 'THE SIZE OF THE

INCREASE OF EACH JOINT IS CON'TROLLED BY THE

MAGNITUDE OF THE FACTOR AX.

$\pitchfork \star \star \star \star \star \star \star *$

IF (INBUE (Q) +4096)67,67,68

$A Y=(-1) *(\operatorname{INBUE}(Q)+4096)$

$A X=(A Y / 400)+$.1 .

GO TO $3 \forall 7$

$68 \quad A W=\operatorname{INBUF}(Q)+4896$

$A X=1 . /(((A W / 50) *.(A W / 4096))+1$.

307 IF (22) $368,368,700$

368 WRITE $(6,301)$

$3 d 1$

FORMAT(IOX 'THE INITIAL VALUES ARE ON THE OUTPUT CHANNELS'/ 
1 LUX It', YUU WISH 'I'HE' PKUGKaM TU CUN'INUE', 'IYYE' + I') $R E A D(6,3 \cup 2) Z 2$

302 HUKMAT(I 3)

Is $(\angle \angle) 38,700,700$

Livo 


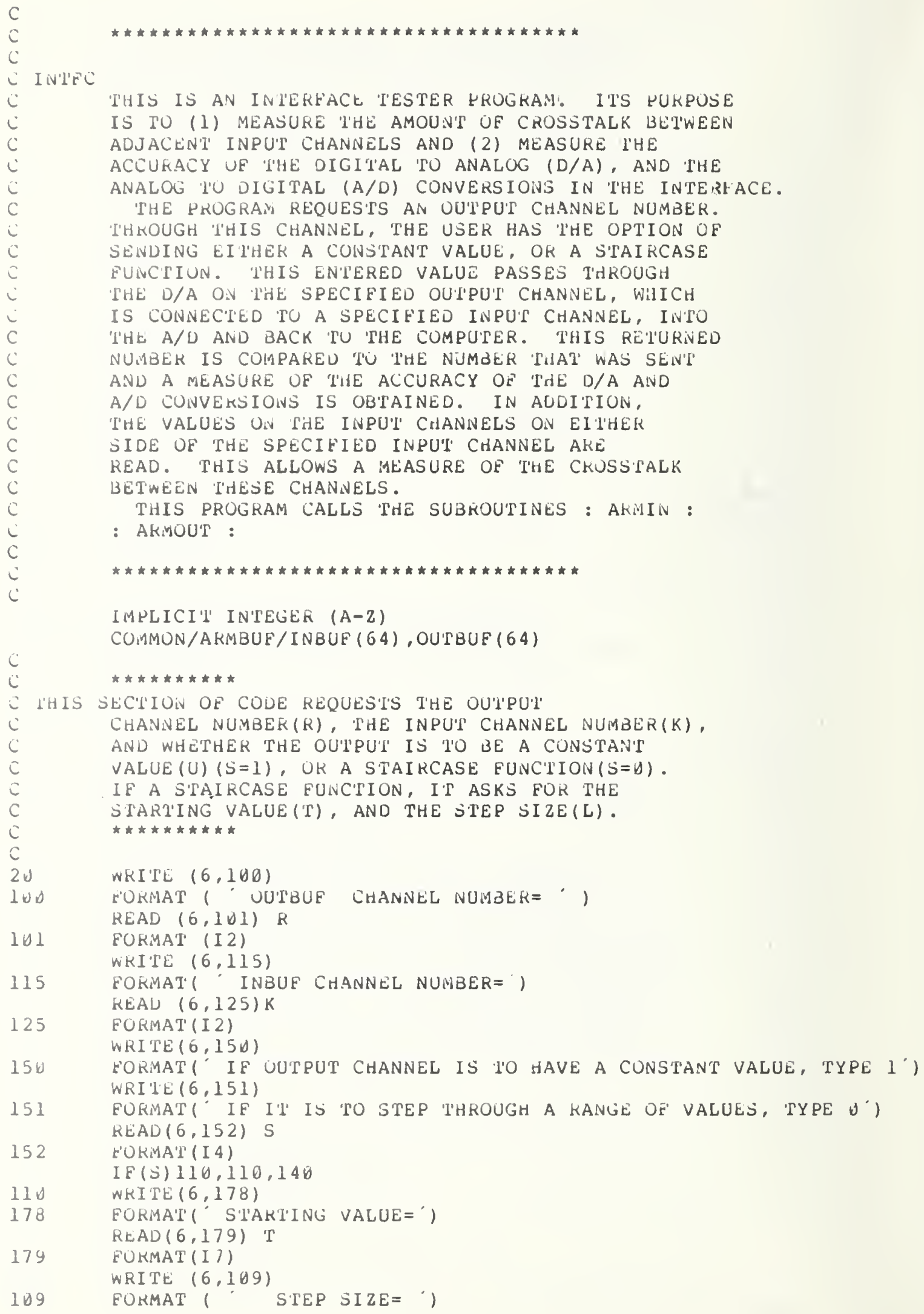




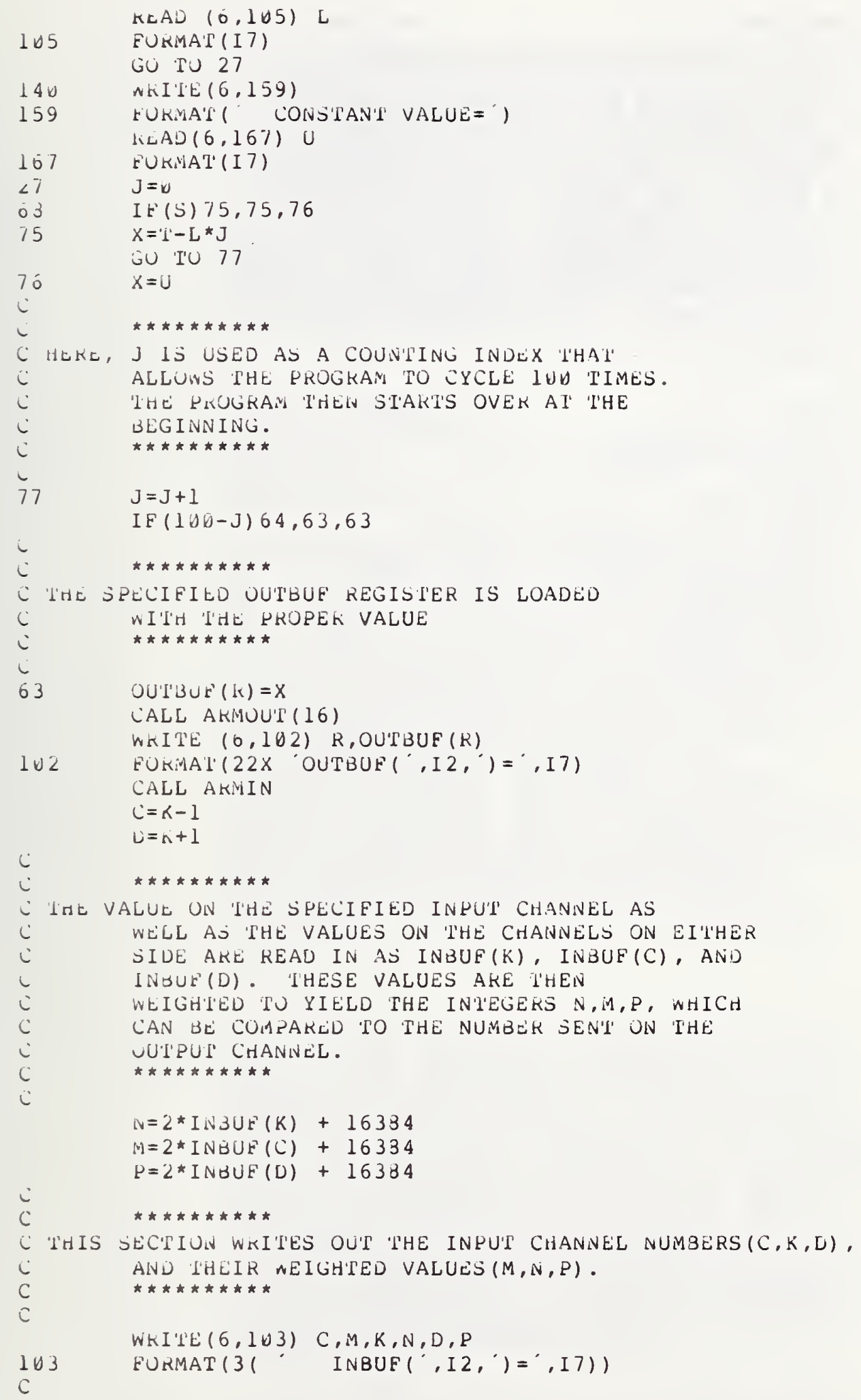







THIS SUJROUIINE IS USED WITH 'IHE PRUGRAM SNW TO GENERATE SINE WAVE OUTPU'SS TO THE JOINTS OF THE MANIPULATIOK. THE PURPOSE OF THIS SUBROUTINE IS (1) TO PREVENT THE ARM FROM TKAVELING TOO GREAT A DISTANCE IN A SINGLE STEP BY PRESCRIBING THE LARGEST AMOUNT THAT THE OUTPUT VALUE IS ALLOWED TO CHANGE, AND (2) TO SET LIMITS ON THE AMPLITUDE OF THE SINE WAVE TU EACH JOINT.

IMPLICIT INTEGER (A-V)

IMPLICI I INTEGER $(X-Z)$

COMMON $/ 2 / 22$

COMMON/ARMBUF/INBUF (64), OUTBUF (64)

DIMENSION AOTBE $(64), \operatorname{CHAN}(20,2)$

\section{IS THE FLAG FROM THE SNW PROGRAM THAT}

HAS A VALUE OF FOR THE INITIAL OU'TPU'I', AND +1 FOR THE REMAINDER OF THE PROGRAM RUN. 22 IS USED HERE TO PREVENT AN ERROR SIGNAL FROM OCCURRING WITH THE INITIAL OUTPUT. THE ERROR SIGNAL ARISES WHENEVER THE DIFEERENCE BETWEEN THE PRESENT OU'TPU'T AND THE PREVIOUS OUTPUT IS GREATER THAN THE SPECIFIED ALLOWABLE CHANGE(B) . FOR THE INITIAL OUTPUT, THE PREVIOUS OUTPUI' IS ZERO, THEREFORE, THE DIFFERENCE WILL PROBABLY BE' GREATER THAN THE SPECIFIED VALUE(B). THUS, FOR $2 Z=\emptyset$, THE PREVIOUS OUTPUT IS SE'T EQUAL TO THE INITIAL OUTPU'T BEFOKE 'I'HE' DIFFEREINCE BETWEEN THEM IS CALCULATED.

$\star \star \star \star \star \star \star \star \star \star$

IF (22) $4,4,5$

C

C I'HIS BLOCK OF CODE EXECUTED FOR THE INITIAL OUTPUTS ONLY. THIS SECIION OF CODE REQUES'SS (1) THE SIZE OF THE ALLOWABLE OUTPU'T CHANGE(B), (2) IF LIMITS ARE TO BE SET ON THE AMPLITUDES OF THE SIGNALS TO ANY UF THE JOINTS (YES(LIMIT=-1), NO(LIMIT=+1)) AND (3) IF LIMITS ARE TO BE SET, IT ASKS FOR THE LOWER LIMIT(CHAN (IJ,1)) AND THE UPPER LIMIT $(C H A N(I J, 2))$ FOR EACH JOINT(IJ). THIS SECTION OF CODE ALSO SETS THE PREVIOUS OUTPUT VALUES (AOTBF(J)) EQUAL TO THE PRESENT INITIAL VALUES (OUTBUF(J)) FOR EACH JOINT(J) EOR THE REASON DESCRIBED ABOVE.

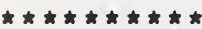

WRITE $(6,227)$ $\left.13 X,(\theta \text { TO } 32767 \text { GIVES + } 10 \text { TO }-10 \text { VOLTS })^{\prime}\right)$ $\operatorname{READ}(6,228) \quad B$ 


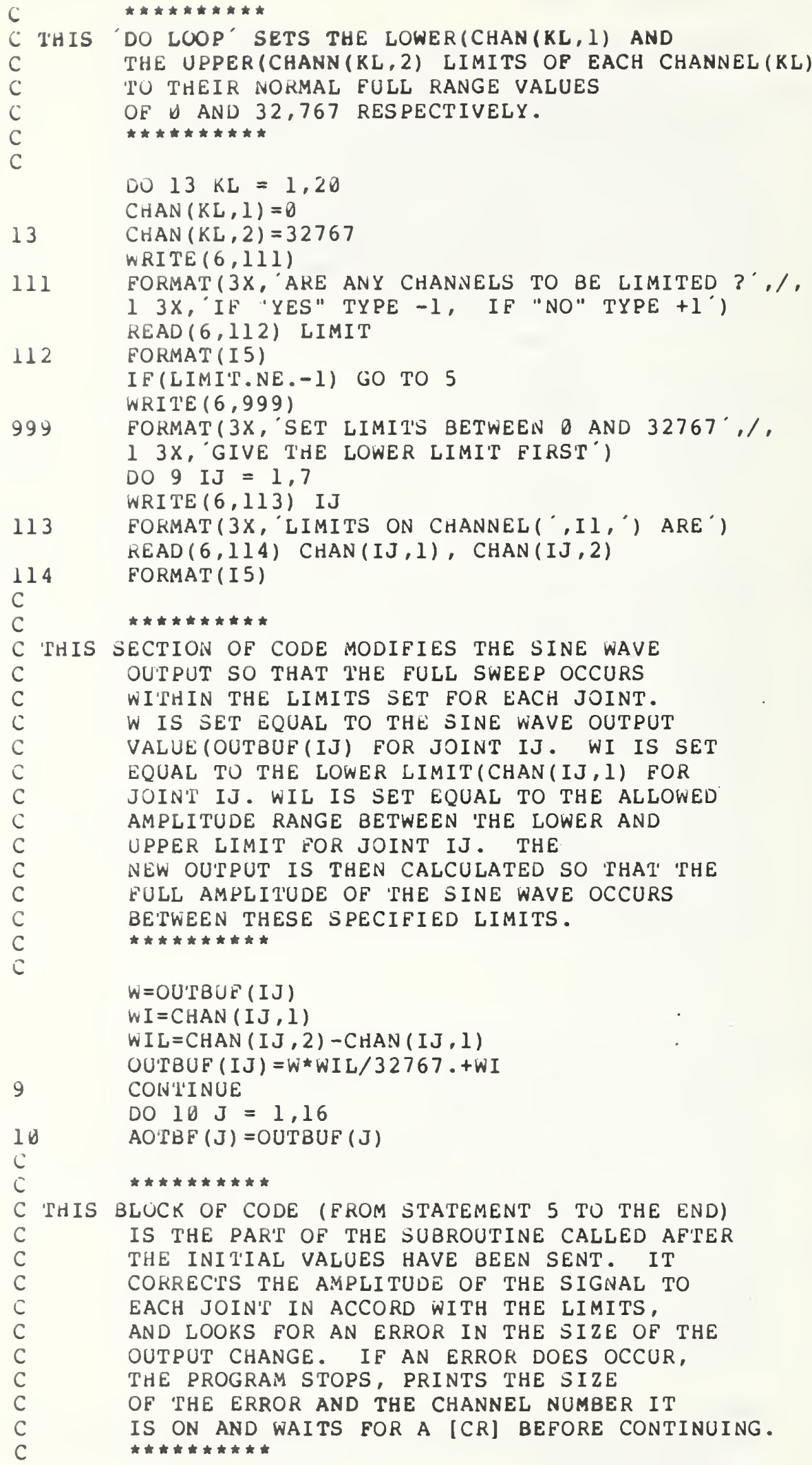




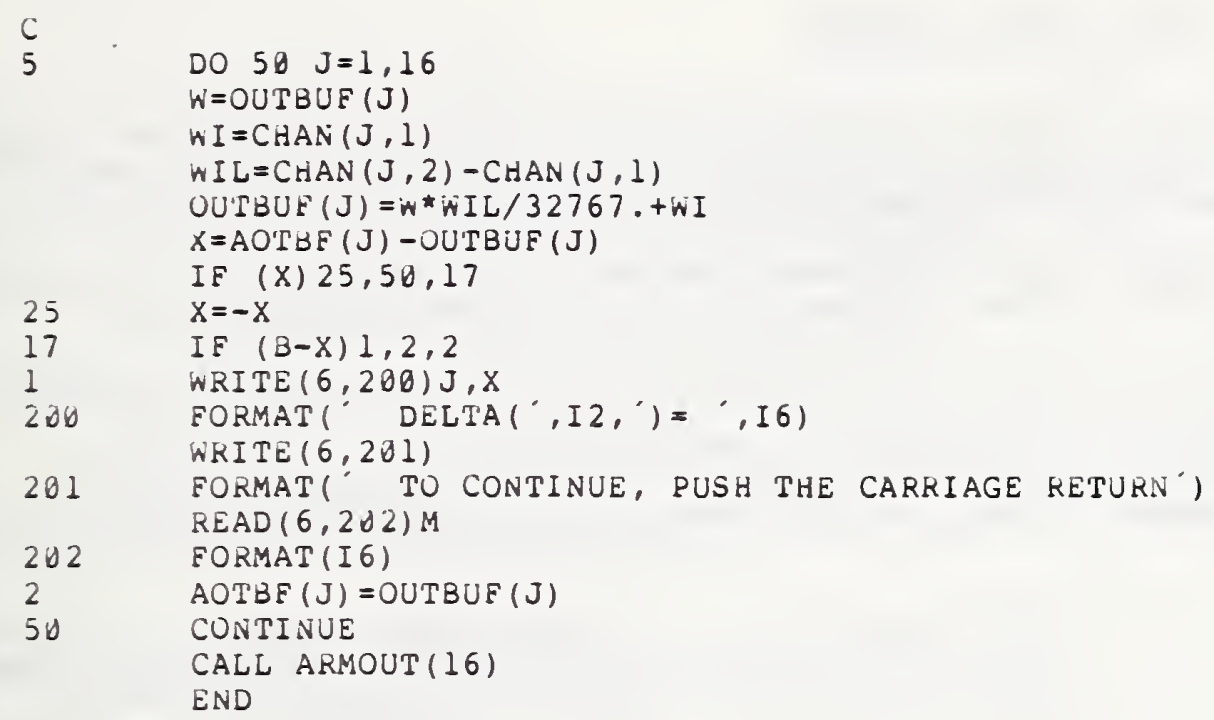




\section{Appendix E: ROBOT CONTROL PROGRAMS}

These programs allow robot control of a manipulator by a mini-computer. Input commands are read from a master (referred to as the exoskeleton in the documentation) and output commands drive the servos of the slave manipulators.

1. SANDF: "Store and forward" for master/slave control. Reads input commands, scales them, and outputs them to the slave manipulator.

2. ARM: Basic robot program with continuous path teaching and playback.

3. PNTPNT: Point-to-point version of ARM.

4. NEWARM: Combines ARM and PNTPNT and adds interpolation if desired on playback.

Note: SANDF needs to know which input channels are which and what scaling factors, if any, are needed to produce the proper output commands to the servos (e.g. in the NBS system the D/A converters require all positive numbers; the value $+16,384$ is zero volts).

Note: NEWARM is the recommended robot program for general use. 
SANDF STANDS FOR STORE AND FORWARD

IT STURES, SCALES AND FORWARDS THE VALUES READ

FROM THE EXOSKELETON (A/D CONVERTED VALUES) TO

'THE' SLAVE ARM (D/A CONVERTED VALUES).

ALL VALUES MUST BE SCALED TO POSITIVE QUANTITIES

AS THE SIGN BIT OF A NUMBER SENT TO THE D/A CONVERTER WILL RESET THE CHANNEL ADDRESS 'IO $\theta$.

IHIS PROGRAM IS USED TO GATHER ALL 64 CHANNELS INTO IHE CUMMON

AREA ARMBUF IN ARRAY INBUF, THEN OUTPUT THE SCALED VALUES

C FROM THE MASIER EXOSKELETON. THERE ARE 7 DEGREES OF FREEDOM.

C 'THE 64 CHANNELS INCLUDE MASTER POSITION POTS, SLAVE POSITION

$C$ POTS SENSORS, AND SENSE SWITCHS.

C

IMPLICIT IN'TEGER(A-Z)

COMMON /ARMBUF/INBUF (64), OUTBUF (64)

C

CALL ARMIN

$\mathrm{C}$

C

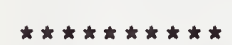

THE FOLLOWING 'TWO 'DO LOOPS' ARE USED TO

GENERATE THE CORREC'T INPUT CHANNEL NUMBERS

$(5,8,11,13,15,17,19)$ FOR THE SEVEN JOINT

PO'TENTIOMETERS.

C

C

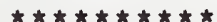

$K=2$

DO $50 \quad I=1,2$

$K=K+3$

OUTBUF (I) $=$ IABS (INBUF $(K) * 2+16383)$

50 CONTINUE

$K=9$

DO 51 I $=3,7$

$K=K+2$

UUTBUF (I) $=$ IABS (INBUF $(K) * 2+16383)$

51 CONIINUE

C

RETUKN

END 
AKM IS A PKUGKAY 'IU STUKE AND FURWARD DATA BE'I'WEEN AN INPU'I CON'TROL DEVICE (EXO-SKELETON) AND A MECHAIICAL MANIPULATOR. AT 'THE OPERATOR'S KEQUES'T, ARIM RECORDS 'I'HE' INPUT DA'I'A FUR SUBSEQUEN'I PLAYBACK -- MUCH LIKE A TAPE RECORDER.

IMPLICI'I' IN'TEGER (A-Z)

DATA IS PASSED BETWEEN THE MAIN PROGRAM AND THE LOWER LEVEL IN'IEREACE DRIVER RUUTINES THROUGH THE COMMON DATA AREA NAMED ARMBUE.

COMMUN/AKMBUE/INBUF (64), OUI'BUF (64)

'I'HE LUCAL BUFEER INCBUF STORES THE INPUI CUORDINATES DURING 'PHE RELORDING SESSION. AT 'THE OPERATOR'S REQUEST, 'THIS RECORDED DATA CAN BE SAVED ON DISK OR TAPE.

DIMENSION INCBUF $(2000,7)$

FOK CUNVENIENCE, A VARIABLE NAMED SWITCH IS EQUIVALENT 'TO THE INPUT BUEEER ELEMENT ASSIGNED TO CHANNEL NUMBER 27. IHIS CHANNEL ENABLES THE OPERATOR TO COMMUNICATE TO THE RUNNING PROGRAM VIA A FUNCIION BUITON LOCATED NEAR THE INPU'T EXO-SKELETON.

EQUIVALENCE (SWI'I'CH, INBUF (27))

FIRST, THE PROGRAM ACCEPTS A REQUEST FROM THE OPERATOR 'TU PLAY BACK A PREVIOUSLY RECORDED TRAJECIORY.

WRITE $(6,1000)$

$\operatorname{READ}(6,1100)$ FILFLG

IF (FILELG .NE. IHY)GOTO 10

IF 'I'HE OPERATER DID REQUEST A PREVIOUSLY RECORDED TRAJEC'TORY 'THE OLD DAT'A VALUES ARE READ IN AND CONTROL TRANSFERS 'TO THE PLAYBACK POR'IION OE THE PROGRAM.

WRI'TE $(6,1010)$

DO $2 I=1,200 B$

$\operatorname{READ}(2,1080, \operatorname{END}=3)(\operatorname{INCBUE}(I, J), J=1,7)$

I I NC $=$ I -1

GOTO 300

IE IHE OPERATUR INTENDS TO CREAIE A NEW TRAJECTORY, THE PROGRAM FIRST ENTERS A LOOP IN WHICH ALL OF THE JOINT ANGLES FROM THE EXO-SKELE'TON AKE FORWARDED TO THE MANIPULATOR. ALSO, THE SWITCH (CHANNEL 27) USED BY THE OPERATOR IS SAMPLED ON EACH PASS THROUGH 'THE LOUP. A COMBINATION OE THE SWITCH VALUE AND THE VARIABLE LATCH IS USED TO CONTROL TIE PROGRAM FLOW.

LATCH=1

I I NC $=1$

EOTHR $=2 \forall$

EOTHRS =EOTHR

WRI TE $(6,1020)$ 


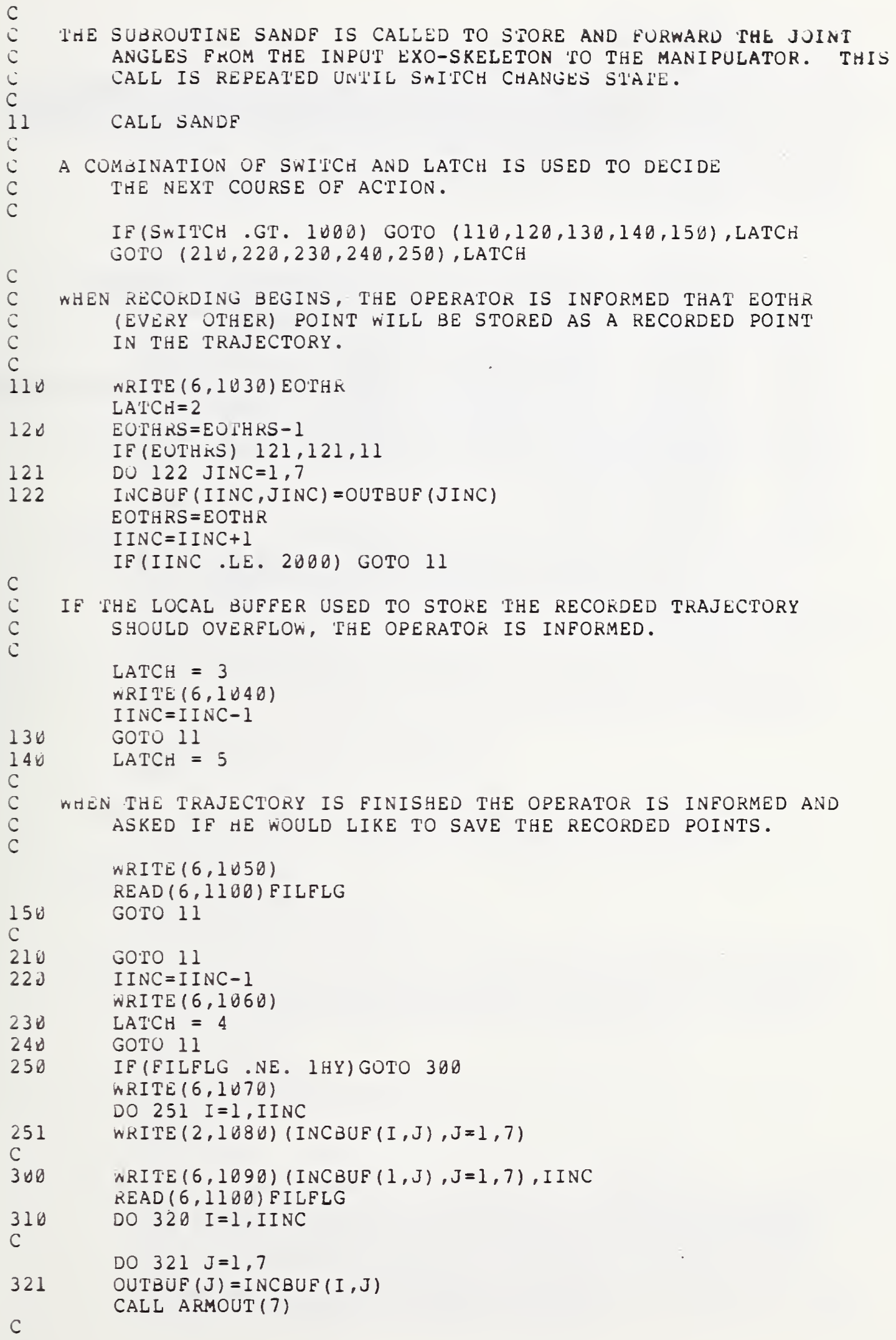




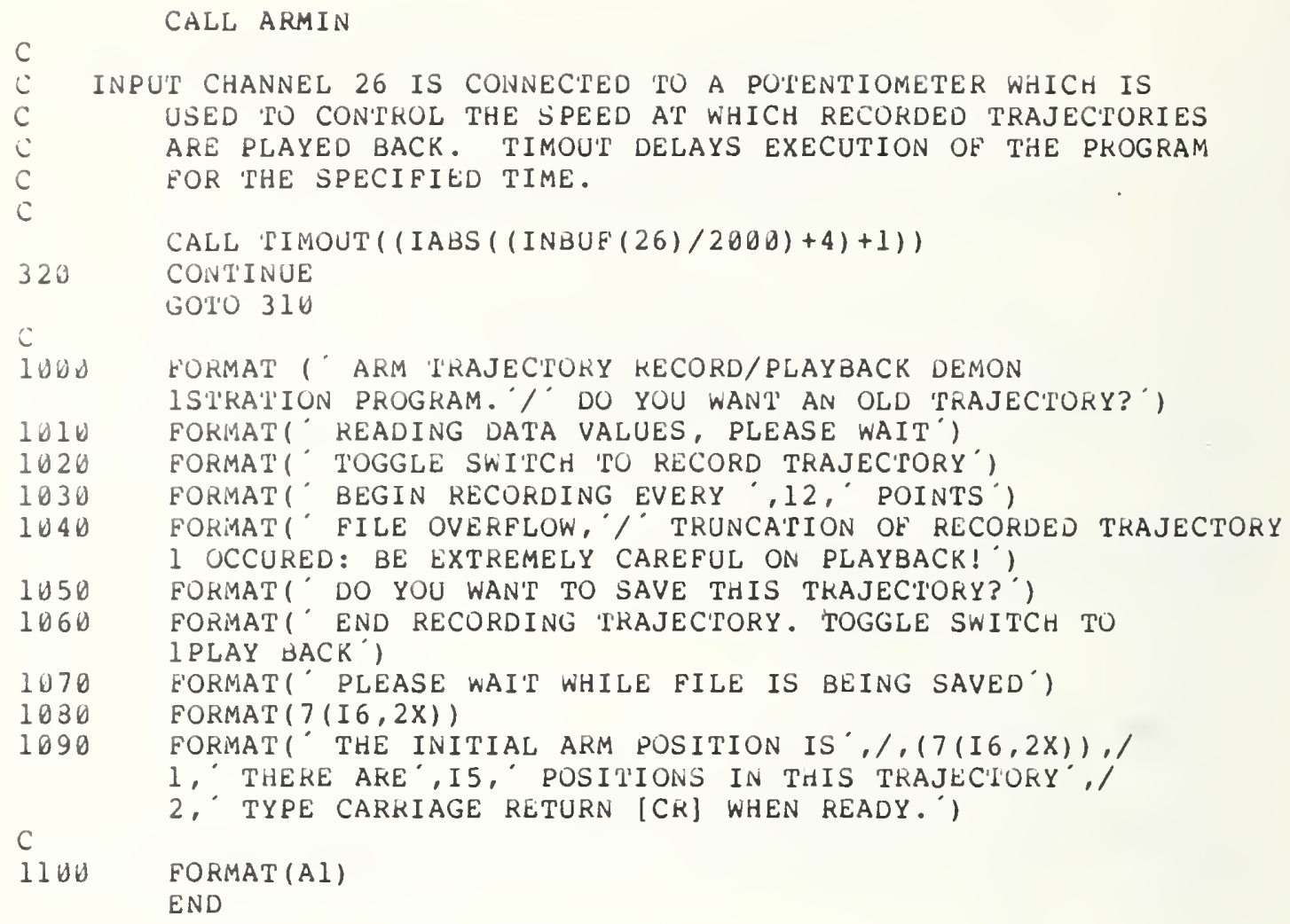




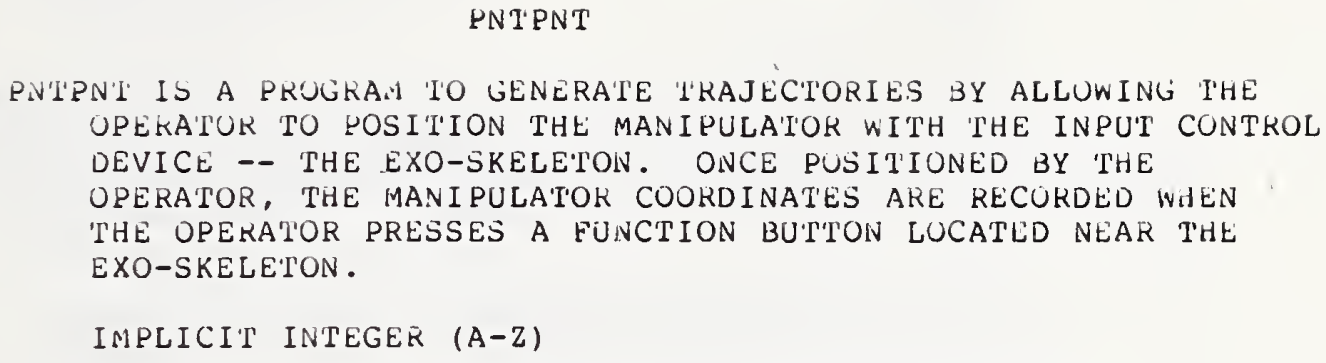

PNIPNI' IS A PRUGRA.I 'IO GENERATE 'I'RAJECIORIES BY ALLUWING 'THE UPEKATUR TO POSI'IION THE MANIPULAIOK WITH 'THE INPUT CONTROL DEVICE - THE EXO-SKELETON. ONCE PUSITIONED BY THE OPERATOR, THE MANIPULATOK COORDINATES ARE RECURDED WIEN 'THE OPERATOR PRESSES A FUNCTION BUT'TON LUCATLD NEAR THE EXO-SKELETON.

\section{IMPLICIT INTEGER $(\mathrm{A}-\mathrm{Z})$}

DATA IS PASSED BETWEEN THE MAIN PROGRAM AND THE LOWER LEVEL INTERFACE DRIVER ROUTINES THROUGH THE COMMON DATA AKEA NAMED ARMBUF.

COMMUN/ARMBUF/INBUF (64), OUTSUF (64)

'THE LOCAL BUFFER INCBUF STORES THE INPUI' COORDINATES DURING 'THE RECORDING SESSION. AT THE OPERATOR'S REQUEST, THIS RECOKDED DATA CAN BE SAVED ON DISK OR 'IAPE.

DIMENSION INCBUF $(2000,7)$

rUR CONVENIENCE, A VARIABLE NAMED SWITCH IS CQUIVALENT TO IHE INPUT BUFEEK ELEMENT ASSIGNED TO CHANNEL NUMBER 27. IHIS CHANNEL ENABLES IHE OPERATOR IO COMWUNICATE TO THE RUINING PRUGRAH VIA A FUNCIION BUT'IOIN LOCATED NEAR THE INPU'I' EXO-SKELETON.

FUNCIION DUITON 2 IS ASSIGNED TO INPU'I CHANNEL NUMBER 28. 'IHIS FUNCIIION BUITON EQUIVALENT TO POINT, IS USED TO IDEIVIIFY A PARIICUAR SET OF COORDINATES TO BE RECORDED.

EQUIVALENCE (SWITCH, INBÜF (27))

EQUIVALENCE (POIN'T, INBUF (28))

EIRS'I, THE PRUGRAM ACCEPTS A REQUEST FKOM 'THE OPERATOK TO YLAY BACK A PREVIOUSLY RECORDED TRAJECTOKY.

WRITE $(6,1000)$

$\operatorname{READ}(6,1100)$ FILFLG

IF (FILFLG. NE. 1HY)GOTO 10

IF 'THE OPERAIOR DID KEQUEST A PREVIOUSLY KECORDED 'TRAJECIORY 'THE OLD DAT'A VALUES ARE READY IN AND CONTROL T'RANSFERS 'TO THE PLAYBACK PORTION OF THE PROGRAY.

WRITE $(6,1 \cup 1 \cup)$

DO $2 I=1,2000$

$\operatorname{READ}(2,1 \cup 8 \mathrm{~B}, \operatorname{END}=3)(\operatorname{INCBUF}(I, J), J=1,7)$

I I NC $=$ I - 1

GOTO 3 U日

IE I'HE OPERA'UUK INTEIVUS 'IO CKEAL'E A NEW 'I'RAJECTORY, THE PROGRAM EIRST EINTERS A LOOP IN WHICH ALL OF THE JOINT ANGLES FRO ${ }^{\circ}$ IHE EXO-SKELETON ARE FOKWARDED TO THE MANIPULATOR. ALSO, 'THE SWITCH (CHS INEL 27) USED BY IHE OPERATOR IS SAMPLED ON EACH PASS THROUGH THE LOOP.

A COMBINATION UF IHE SWITCH VALUE AND THE VARIABLE LAICH IS USED TO CONTROL THE PROGRAM FLOW. 


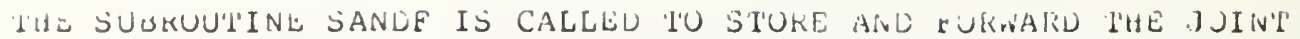
ANGLES FKUM 'IHE INPU' EXO-SKELEION I'O THE MANIPULATOR. THIS CALL IS KEPEATED UNIIL SWI'ICH CHANGES STAIE.

CALL SANDF

A COMBINATIUN UE SWIICH AND LATCII IS USED TO DECIDE 'THE NEXI' COURSE OF AC'IIION.

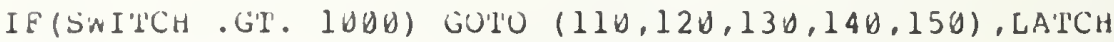
GU'U $(210,22 \theta, 23 \theta, 246,250)$, LA'LH

WHEN KECORDING BEGINS, IHE OPERAIOR IS INFORMED THAI' FUNC'IION BUITUN INUMDER 2, (INPUI' ON CHANNEL INUMBER 28) IS USED 'TO RECOKD THE LOCA'IUN UF 'THE MAIVIPULATOR A'I' I'TS CURKENT PUSI'IION.

$110 \quad$ NRI'LE $(0,1036)$

LA'IHC $=2$

12日 IF(POIN'I .LI'. 1U00)GU'O 11

121 DO $122 \mathrm{JINC}=1,7$

$122 \operatorname{IINCBUE~(IINC,JINC)~=OUTBUF~(JINC)~}$

EUI'HKS=EOTHR

I I NC = I I NC +1

IF(IINC . LE. 2UOV) GUTO 11

$c$
C
c

IE 'PHE LUCAL BUF'FER USED TO STORE 'THE RECORDEO TRAJEC'IORY SHOULD OVEKELUW, IIHE OPERAIOK IS INEORIEU.

$\mathrm{LATCH}=3$

WRITE' $(6,1 \cup 46)$

I I NC $=$ I I INC -1

$13 \mathrm{G} \quad \mathrm{GO} 1 \mathrm{O} 11$

$14 \mathrm{v} \quad \mathrm{LAICH}=5$

¿

U

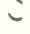

i

WHEN 'IHE 'IKAJELIUKY IS FINISHED THE OPERATOR IS INFOKMED AND ASKED IE HE WOULD LIKE 'IU SAVE THE RECOKDEU PUINTS.

WRI'IE $(6,1050)$

$\operatorname{READ}(6,1100)$ EILFLG

150 GOIU 11

C

GOTU 11

22b II NC $=$ I INC -1

WRITE $(6,1060)$

23v LATCH $=4$

24V GOTO 11

250 IF(FILFLG . NE. 1HY)GOTO $30 \%$

WRITE $(6,1070)$

DO $251 \mathrm{I}=1$, I INC

251

WRITE $(2,1080)(\operatorname{INCBUE}(I, J), J=1,7)$

i

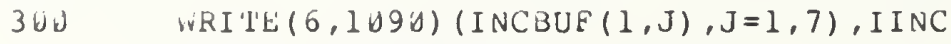

310 $\operatorname{KEAD}(6,1100)$ EILFLG

C DO $32 v I=1$, I I NC 
DU $321 \mathrm{~J}=1,1$

$\operatorname{OUTBUE}(J)=\operatorname{INCBUF}(I, J)$

CALL AKMOU'I' (7)

CALL ARMIN

INPU'l' CHANNEL 20 IS CONNECl'EO TO A POTEINIOMETER WHICH IS USED TO CON'TKUL THE SPEED A'I WHICH RECOKDED 'IKAJECTORIES AKE PLAYED BACK. 'IIMOU'I DELAYS EXECUTION OF 'I'HE PROGRAM FOK THE SPECIFIED TIME.

CALL TIMOUT ( (IABS ( (INBUF $(26) / 2$ UUb) +4)+1))

320 LONIIINUE

GOTO 316

C

I WUE EURMAT' ' ARM 'IKAJEC'IOKY KECOKD/PLAYBACK DEMON

ISIRAIION PRUGRAM. '/" DU YOU WAN'T AN OLD TRAJECTORY?')

IUIU EORMAT(" READING DATA VALUES, PLEASE WAI T')

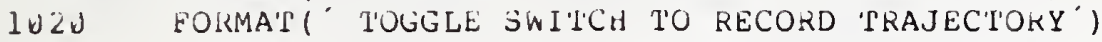

1036 FORMAT( POSITION 'IHE MANIPULATOR 'IO 'IHE DESIREO CUORDINATES . 1. 'THEIN, PUSH BU'T'ION 2 TO RECURD THE POINT.')

IU 4 FORIAT' (" FILE OVERELOW, " " TRUNCATION OF RECORDED 'TRAJECIOKY 1 OCCURED: BE EXIREMELY CAREFUL UN PLAYBACK!')

1056 FOKMAT(' DU YOU NANT 'TO SAVE 'IHIS 'IRAJECTORY?')

IU66 FORMAT! EIV KECORDING TRAJEC'TORY. 'TOGGLE SWI'I'CH 'I'O I LLAY BACK')

IV76 FOKMAT(' PLEASE WAIT NHILE FILE IS BEING SAVED')

1030 FOKMAT(7 (I $6,2 X))$

LU90 FORMAT(' THE INITIAL ARII POSI'IION IS $, 1,(7($ I $6,2 X)), 1$ 1, 'THEKE ARE', I5,' POSITIONS IN I'HIS 'I'RAJEC'TORY", /

2,' 'TYPE CARRIAGE RETURN [CR] WHEN READY.')

1100

EOKMAT (AI)

END 
THIS PROGRAY IS A MODIEIED VERSION JF 'THE ARM PROGRAM. A LARGE PART OF THE CODE, THEREFORE, IS IDENIIICAL AND WILL NOT BE DOCUMENIED HERE. LIKE AKM, THIS PROGRAM ALLOWS

UPERATUR TO RECORD A DESIRED TRAJEC'TORY AND EITHER PLAY IT' BACK IMMEDIATELY OR STORE IT ON DISC TO BE PLAYED BACK AT A LATER TIME. RECORDING THE 'I'RAJEC'TORY CONSISTS IN STORING THE VALUES OF THE POTENTIOMETERS ON EACH OF THE JOIN'TS AS THE MANIPULATOR MOVES THROUGH A SEQUENCE OE MOVEMENTS. TO PLAYBACK, THESE VALUES ARE SEN'I

IN THE SAME SEQUENCE TO THE SERVOS OF ALL OF THE JOINTS.

THIS PROGRAM PROVIDES THE OPERATOR WITH THREE OPTIONS WITH REGARDS TO THE MANNER OF RECORDING 'IHE 'IRAJECTORY.

(1) A CUNTINUOUS PATH RECORDING IDENTICAL TO 'IHE ARM PROGRAM. BY CONTINUOUS PATH IS MEANT THAT THE POTENTIOMETER VALUES ARE CLOCKED IN WITH A CUNSTANT TIME INTERVAL THROUGHOU'T THE RECORDING SESSION.

(2) A POINT-TO-POINT RECORDING. HERE, THE POIENTIOMETER VALUES ARE READ INTO THE COMPUTER ONLY ON COMMAND FROM THE OPERATOR. THE [CR] IS DEPRESSED EACH TIME A POIN'T IS TO BE' READ.

(3) A TWO PUINT TRAJEC'TORY. IN THIS CASE ONLY THE SIARTING PUINT AND THE ENDING POINT ARE RECORDED.

DURING THE PLAYBACK OF BOIH THE CONIINUOUS PATH AND THE POINT-TO-POINT TRAJECIORIES, AN INTERPOLATION ROUTINE IS USED TO GENERATE ADDIIIONAL PUINTS BETWEEN THE RECORDED. PUINTS. THIS PROVIDES A SMOOTHER PLAYBACK TRAJEC'IORY, AND ALSO PROVIDES A CONTROL ON THE SPEED THAT THE IRAJECTORY RUNS. THIS SPEED CUNTROL IS ACCOMPLISHED BY SENDING POINTS 'IO THE AKM A'T A CONSI'AN'T RATE WHILE THE NUMBER OF ADDITIONAL POINIS GENERATED BETWEEN THE RECORDED POINTS IS A FUNC'TION OF THE VOLTAGE LEVEL ON INPU'T CHANNEL 26 (THIS IS 'IHE PUTENTIOMETER ON THE FUNC'TION KEYBOARD. I'I' IS ALSO THE VALUE Q FUK THE SNW PROGRAM . ) .

'IHE TWO PUINT TRAJECTOKY DUES NU'I' IICOKPOKATE 'THIS INTERPOLATION ROUTINE. THUS DURING PLAYBACK 'IHE ARM TRAVELS AT IT'S HIGHES'I' VELOCI'TY FROM THE STARTING TO THE ENDING POINT. ITS ABILITY 'TO PERFORM THIS TYPE OF TRAJEC'TORY TO AN END POINT WITHIN ITS SPECIEIED ACCURACY IS PART OF THE ACCEPTANCE PROCEDURE. 


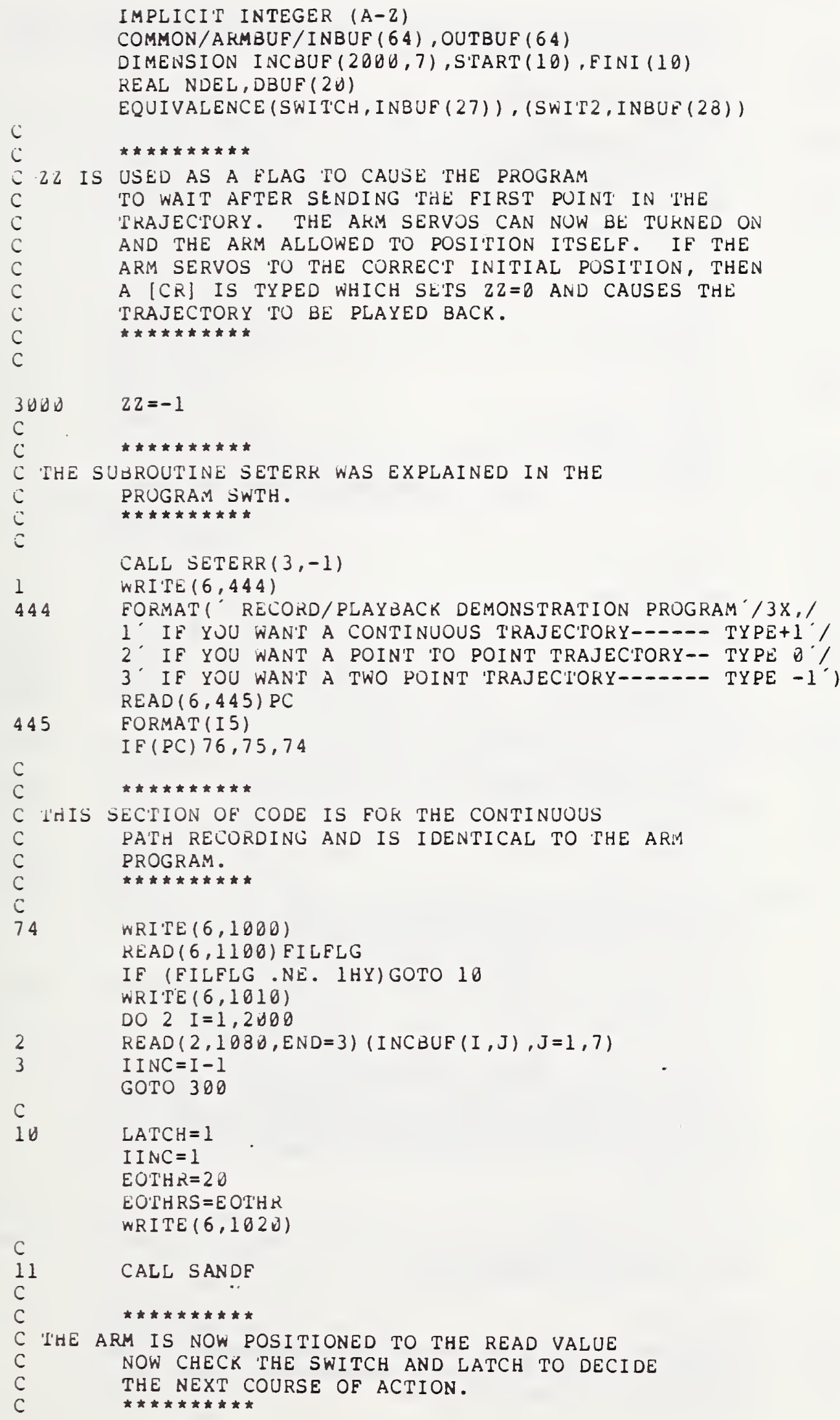




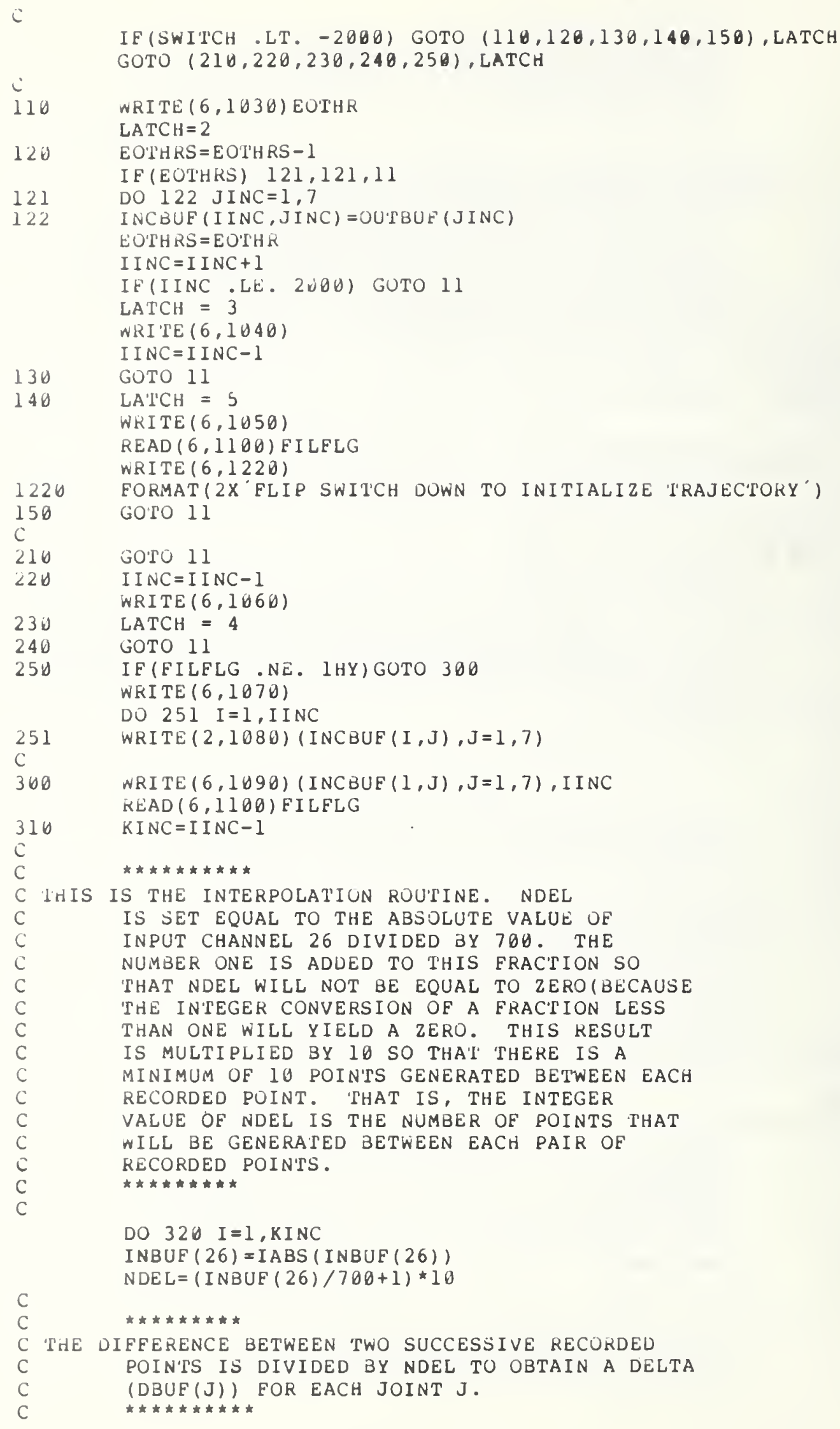




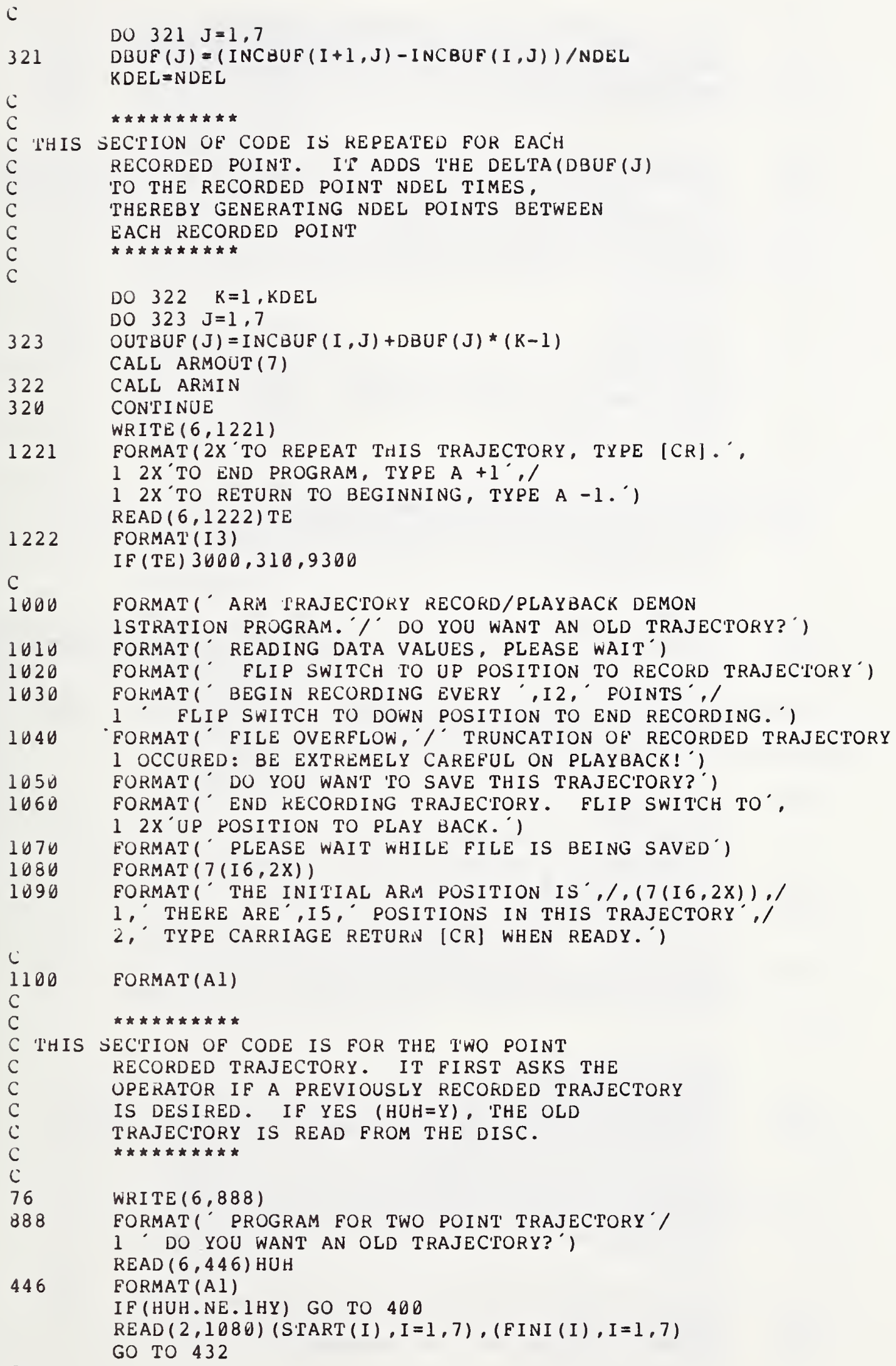




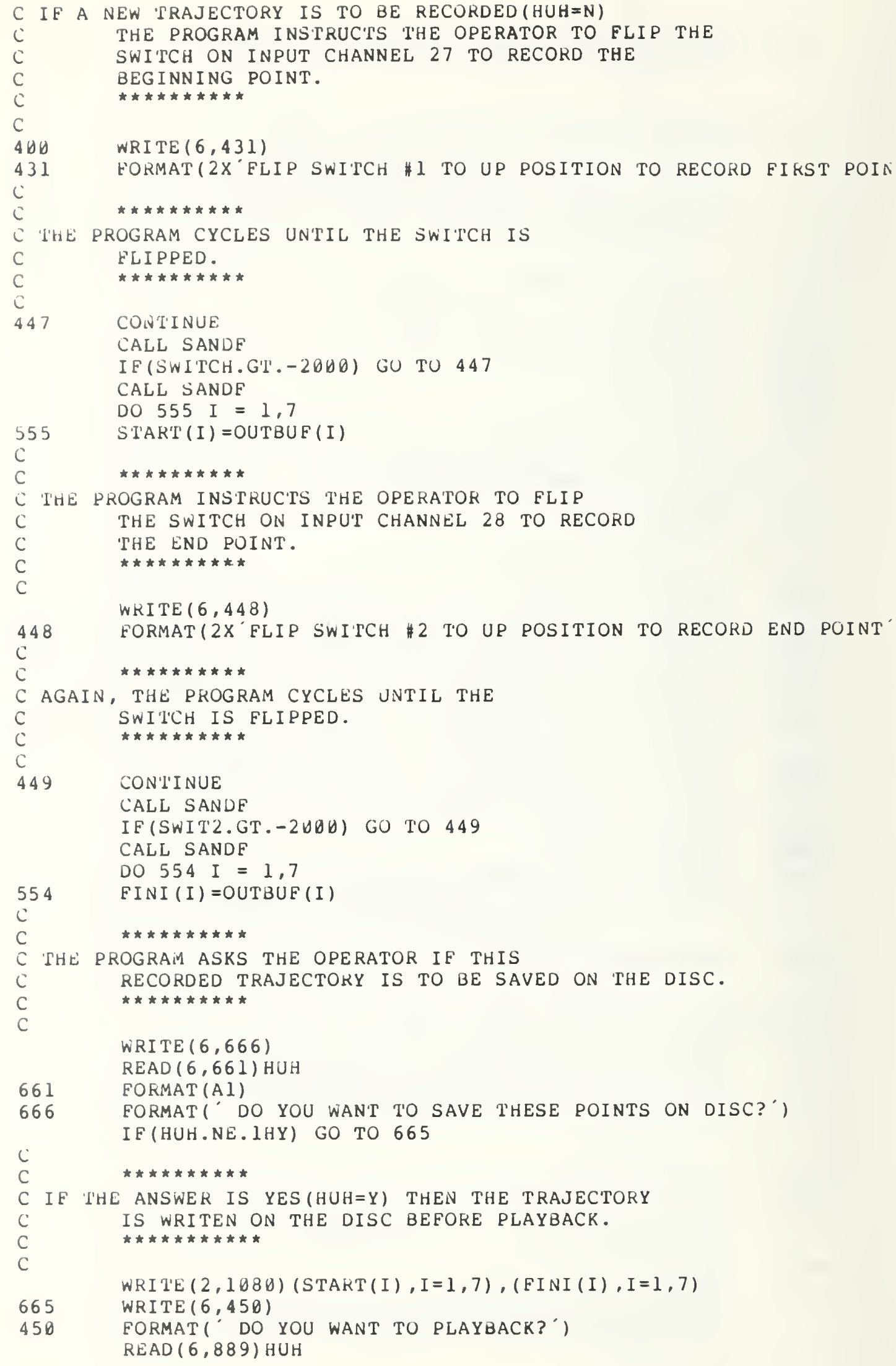




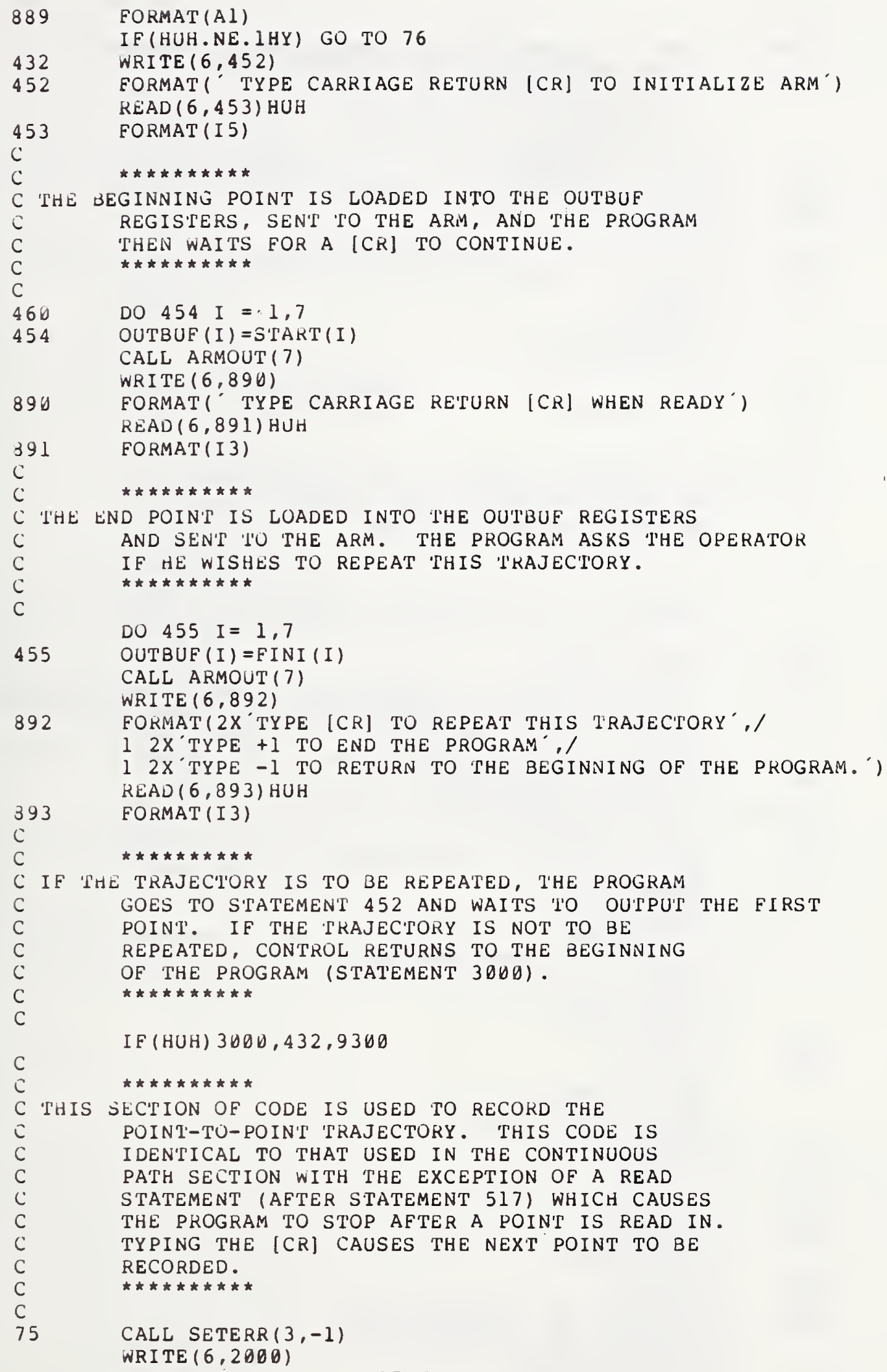




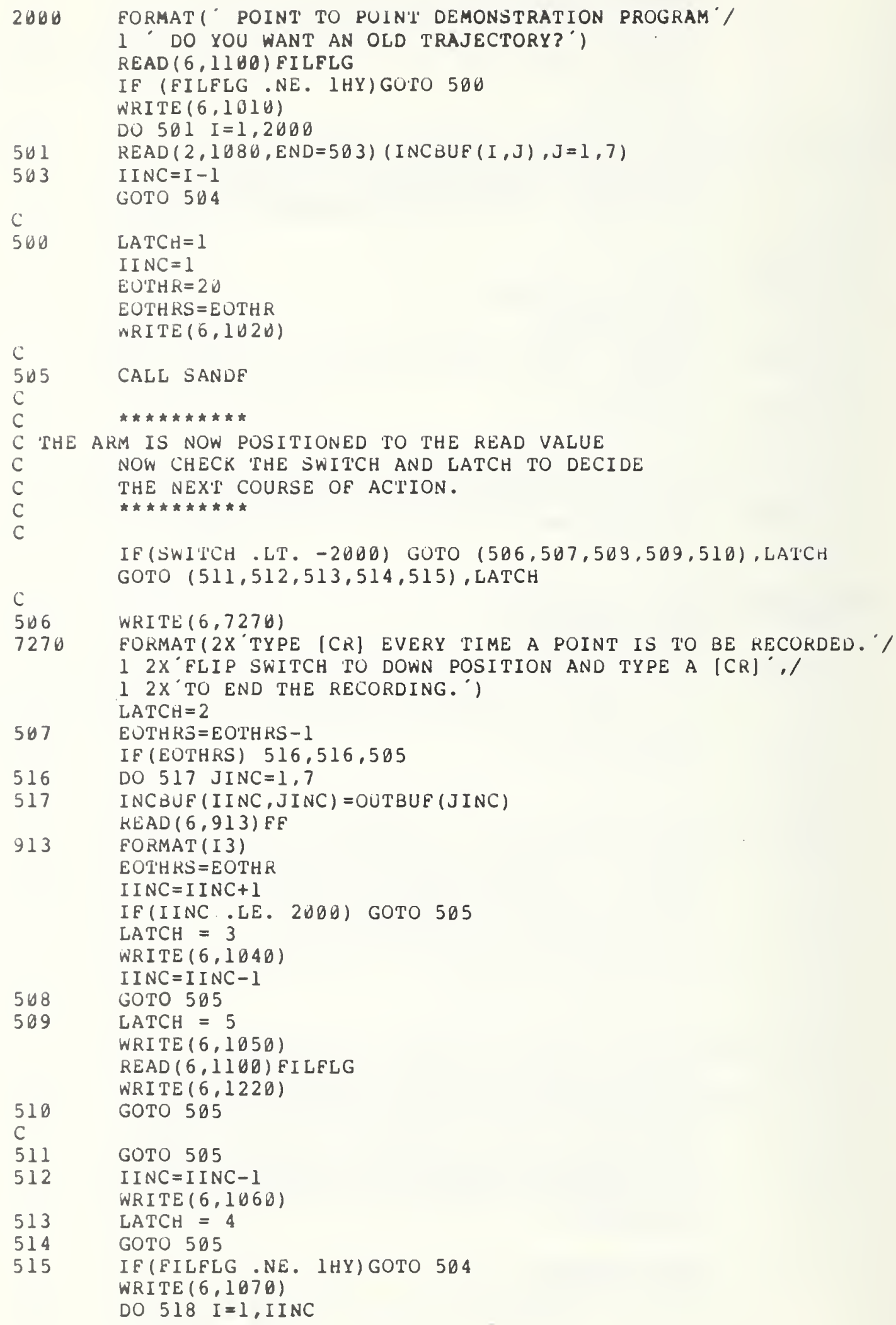




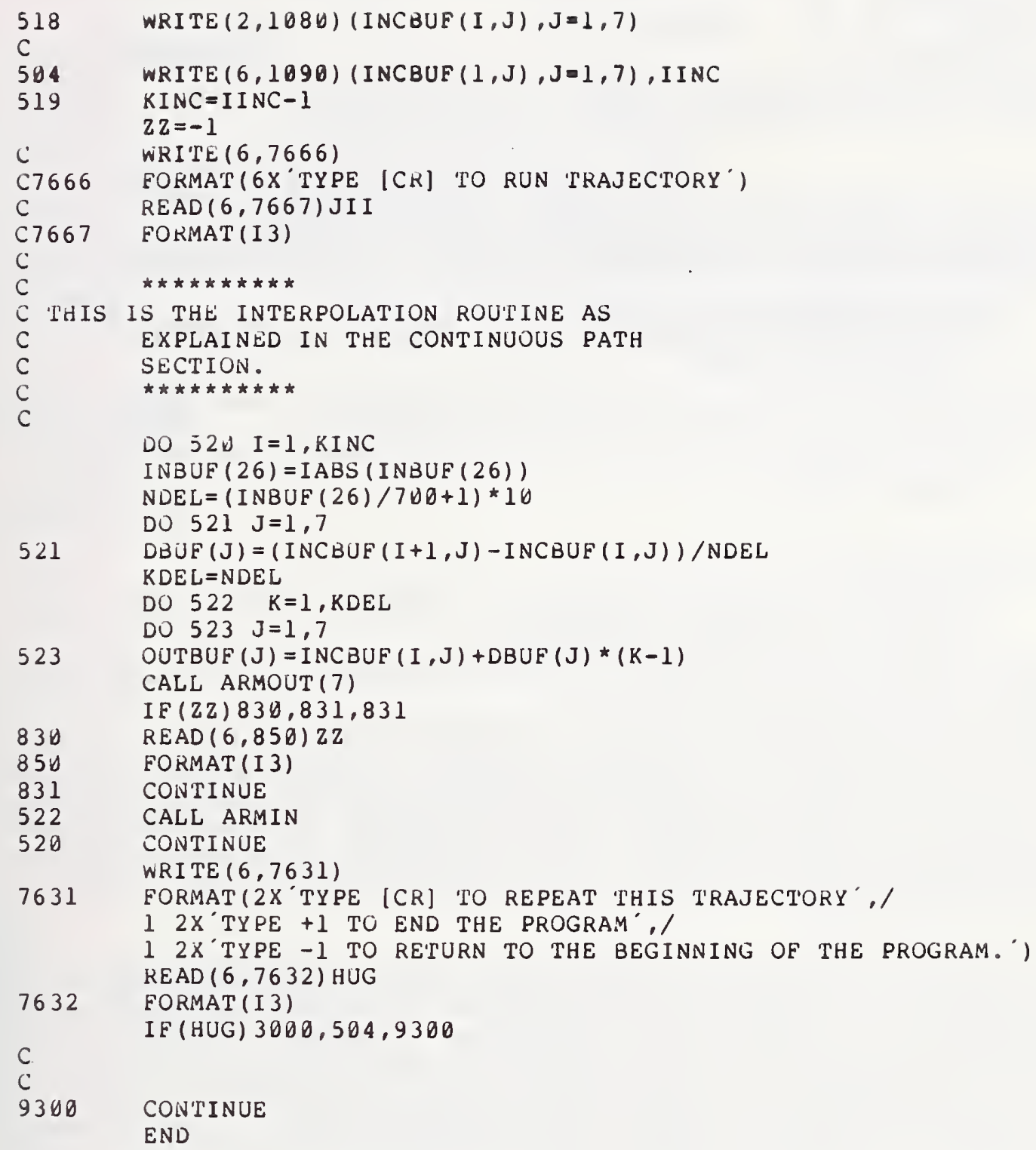




\begin{tabular}{|c|c|c|}
\hline $\begin{array}{c}\text { U.S. DEPT. OF COMM. } \\
\text { BIBLIOGRAPHIC DATA } \\
\text { SHEET }\end{array}$ & $\begin{array}{c}\text { 1. PIHI.K ATION (OR RFPORT NO. } \\
\text { NBSIR 75-973 }\end{array}$ & $\begin{array}{l}\text { 2. Cov't ACcession } \\
\text { No. }\end{array}$ \\
\hline
\end{tabular}

4. TITI.E AND SUBTITI.I:

GUIDE TO IMPROVING THE PERFORMANCE OF A MANIPULATOR SYSTEM FOR VUCLEAR FUEL HANDLING THROUGH COMPUTEK CUNTKULS.
5. Publication Date

November 1975

6. Performing Organization Code

7. AUTHOR(S) Drs. John M. Evans, Jr., James S. Albus \& Anthony J. Barbera and Mr. Robert Ronsenthal and Mr. William B. Truitt 9. PERFORMING ORGANIZATION NAME ANI) ADDRESS

NATIONAL BUREAU OF STANDARDS DEPARTMENT OF COMMERCE WASHINGTON, D.C. 20234

8. Performing Organ. Report No.

10. Project/Task/Work Unit No. 6006111

11. Contract/Grant No

12. Sponsoring Otganization Name and Complcte Address (Street, City, State, ZIP)

Same as iten 9

13. Type of Repore \& Period Covered

Final

14. Sponsoring Agency Code

15. SUPPLIEMENTARY NOTLS

This is an Interagency report to be presented to Oak Ridge National Laboratory, Oak Ridge, Tennessee.

16. ABSTRACT (A 200-word or less factual summary of most significant information. If document includes a significant bibliography or literature survey, mention it here.)

The Office of Developmental Automation and Control Technology of the Institute for Computer Sciences and Technology of the National Bureau of Standards provides advising services, standards and guidelines on interface and computer control systems, and performance specifications for the procurement and use of computer controlled manipulators and other computer based automation systems. These outputs help other agencies and industry apply this technology to increase productivity and improve work quality by removing men from hazardous environments.

In FY 74 personnel from the Oak Ridge National Laboratory visited NBS to discuss the feasibility of using-computer control technqiues to improve the operation of remote control manipulators in nuclear fuel reprocessing. Subsequent discussions led to an agreement for NBS to develop a conceptual design for such a computer control system for the PaR Model 3000 manipulator in the Thorium Uranium Recycle Facility (TURF) at ORNL. This report provides the required analysis and conceptual design. Complete computer programs are included for testing of computer interfaces and for actual robot control in both point-to-point and continuous path modes.

17. KEY WORDS (six to twelve entries; alphabetical order; capitalize only the first letter of the first key word unless a proper name; separated by semicolons)

Computer control of automation systems; computer interface; computer software for robot control; hierarchical control of manipulators; position servos; trajectory control.

\begin{tabular}{|c|c|c|}
\hline 18. AYAILABILITY & $\begin{array}{l}\text { 19. SECURITY CI.ASS } \\
\text { (THIS REPURT) }\end{array}$ & $21_{1}$ NO. OF PAGES \\
\hline [ For Official Distribution. Do Not Release to NTIS & UNCL ASSIF IED & 54 \\
\hline $\begin{array}{l}\text { [] Order Frum Sup. of Doc., U.S. Government Printing Office } \\
\text { Washington, D.C. } 20402, \text { SD Cat. No.C13 }\end{array}$ & $\begin{array}{l}\text { 20. SECURITY CLASS } \\
\text { (THIS PAGE) }\end{array}$ & 22. Price \\
\hline $\begin{array}{l}\text { Xux Oeder From National Technical Information Se } \\
\text { Springfield, Virginia 22151 }\end{array}$ & UNCLASSIFIED & $\$ 4.50$ \\
\hline
\end{tabular}

